\title{
Is The Aeneid Relevant to Modern Leadership?
}

by

Mark J. Ahn

\author{
A thesis \\ submitted to the Victoria University of Wellington \\ in fulfilment of the \\ requirements for the degree of \\ Master of Arts in Classics
}

Victoria University of Wellington 


\begin{abstract}
This thesis explores the Aeneid, Virgil's foundation epic of the Latin canon, from a values-based leadership perspective, which is defined as the moral foundation underlying stewardship decisions and actions of leaders. The Aeneid was originally written to enhance the political legitimacy of the Augustan principate, deliver a cohesive national identity, and extol traditional Roman virtues - all of which were deemed critical to the peace, prosperity and effectiveness of the Roman imperium. Further, this study reviews the epic in its historical context, codes the themes of its key leadership lessons, and employs a mixed-method research framework to juxtapose the leadership lessons identified to the demands of modern leadership. Specifically, the Aeneid is analyzed to juxtapose the resonant leadership elements of vision, culture and values - and their corresponding equivalent Roman themes of fatum, pietas, and virtus.

Whether viewed qualitatively or quantitatively - in the first century BCE Rome of Virgil or across modern sectors (i.e., for profit, non profit, government) - results from this study suggests that rather than bowing to the illusion that current events (e.g., globalization, communication, computing) are beyond ancient insights, this study affirms the unequivocal relevance of the Aeneid to the demands of modern leadership. First, a compelling vision, larger than any individual, is found to be necessary for organizational success and sustainability in the Aeneid, contemporary Rome, and modern organisations. Second, nurturing the culture or prevailing attitudes, beliefs and preferences through multiple approaches, including symbols and rituals, is affirmed to be a critical aspect of organisational leadership which is shared by ancient and modern leaders alike. Third, the Aeneid was coded into the following eight values (or virtus) in order of importance: integrity, good judgment, leadership by example, decision-making, trust, justice/fairness, humility, and sense of urgency. Of note, integrity was by found to be the most superordinate, essential and resonant value by far-without this the other values are severely lessened in worth.

Far beyond transmitting a worn standard diatribe of stoic Greco-Roman values, the Aeneid timelessly illustrates the tensions and tradeoffs facing leaders amidst changing circumstances, challenges, and resource constraints. Far beyond being wooden and moralistic, Virgil adjures leaders to reflectively struggle with inner conflict and growth as they decide on what changes to seek and to what moral foundations must be steadfastly adhered. Far from simply promulgating a celebratory, self-aggrandizement of the Augustan regime, the Aenied echoes an arching vision of the Roman imperium which is universally rooted in the rule of law and climbs to the highest aspiration of mankind's advancement. In sum, while the Aeneid extols prototypical values, the epic instructs that truly effective leadership is not about being a monochromatic prototype. Rather, the epic reveals that the essence and privilege of effective leadership demands reflection on the dynamic relationship between the leader and the led towards a better, envisioned future.
\end{abstract}

Keywords: Aeneid, Augustus, leadership, Roman imperium, vision (fatum), culture (pietas), value (virtus), Virgil 


\section{Acknowledgements}

The author would like to gratefully acknowledge the generous and gracious help, support and guidance of Professor Matthew Trundle for this thesis, as well as the participants who provided their insights and inspiration. I would also like to offer my heartfelt appreciation for the moral support and patience of my wife Shaun in pursuing this long held aspiration. This work is dedicated to her. All errors are my own. 


\section{Table of Contents}

Abstract.................................................................................ii

1. Introduction................................................................1

2. Background of the Aenied...............................................

3. Methodology \& Values-Based Leadership Themes...........................21

4. Results.....................................................................72

5. Conclusion................................................................90

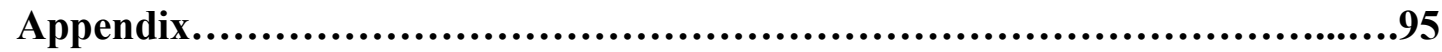

References................................................................98 


\section{List of Figures}

- Figure 1: Virgil reading the Aeneid to Augustus and Octavia, 1787, by JeanJoseph Taillasson

- Figure 2: Map of the journey of Aeneas from Troy throughout the Mediterranean to Latium from an early copy of the Aeneid

- Figure 3: Aeneas, Anchises, and Ascanius Fleeing Troy, 1596, by Federico Barocci

- Figure 4: Leadership Elements and Roman Themes in the Aeneid

- Figure 5: Great Seal of the United States of America denoting novus ordo seclorum (new order of the ages) from the Eclogues

- Figure 6: Johnson \& Johnson Credo

- Figure 7: Venus Requesting Vulcan to Make Arms for Aeneas (c. 1690-1700) by Charles de La Fosse (1636-1716)

- Figure 8: Value trade-offs in a free society as moral choice between four poles: liberty, equality, community and efficiency

- Figure 9: Biogen-Idec Vision, Mission and Core Values

- Figure 10: Rankings of Values by Leaders

\section{List of Tables}

- Table 1: Corporate Practices and Images

- Table 2: Descriptive Statistics of Rankings by Multisectoral Leaders

- Table 3: Leadership Themes and Roman Elements, Leadership Frameworks and Practical Management Implications from the Aeneid

\section{Appendix}

- Appendix A: Structured Interview Questions

- Appendix B: Human Ethics Committee Approval 


\section{Introduction}

\subsection{Leaders and Leadership}

Despite significant changes in technological progress and organizational forms, the study of leaders and leadership has been a perennial source of abiding interest and inquiry as societies have evolved from tribal communities in the mists of time to nation-states with modern global, multinational enterprises and multilateral institutions (MacGregor Burns, 1978; Leebaert, 2006). The narrative depicting the heroic traits and human flaws of the "good king" have evinced timeless characters in the western epic tradition from Sumerian Gilgamesh to Achilles of Homeric fame who displayed immortal heroism, despite a fatal flaw; to King Creon in Sophocles' Antigone who demonstrates the struggles between the rule of law and nature; to the Danish King in Beowulf who instructs us that "admired behaviour is the path to power amongst peoples everywhere"; to The Prince of Machiavelli who educates on the use and limits of power; to Henry $V$ of Shakespeare who illustrates that courage and resourcefulness can overcome overwhelming odds. In these contexts, literature serves as a metronome for the values of society (Moerk, 1998). These and countless other narratives fill the pantheon of great literature and biography, and continue to inspire new generations of audiences and aspiring leaders alike.

This thesis focuses on exploring Virgil's (70-19 BCE) Latin epic poem the Aeneid ${ }^{l}$ from a values-based leadership perspective in its original context as a founding myth, as well as its relevance and implications for the demands of modern leadership. Originally written to enhance the political legitimacy of the Augustan regime (Korfmacher, 1956; Cairns, 1989; Bell, 1999), it was also aimed to extol and glorify values-based leadership captured in

\footnotetext{
${ }^{1}$ All primary quotes of the Aeneid from: Virgil (1983). The Aeneid. (R. Fitzgerald, Trans.). New York, NY: Random House. (Original work published c. 20 B.C.). Hereafter, only book and lines numbers will be cited.
} 
traditional Roman virtues (e.g., pietas — reasoned judgment and performance of one's duties towards followers and family; stoicism — wisdom, courage, justice, and temperance; servant leadership - service to the State before self) which were deemed critical to the peace, prosperity and effectiveness of the Roman imperium (Hahn, 1931; Hammond, 1933; Edwards, 1960; Earl, 1967; Galinsky, 1996; Holland, 2004). The epic also provides deeper insights from a leadership perspective as "the Aenied puts forward a program of values that both noncontroversially reproduces conventional Roman formulations and at the same time makes clear that acceptable subscription to the program cannot take the form of uncritical conventionality, but must consist of vigorous, vigilant interrogation and reflective scrutiny" (Toll, 1997, p. 53). This thesis will juxtapose the resonant leadership elements of vision, culture and values found in the Aeneid - and their corresponding equivalent Roman themes of fatum, pietas, and virtus - to the demands of modern leadership.

\subsection{Context of the Aeneid}

Virgil wrote his epic in the wake of a century of turmoil. Three generations of civil war and internal struggle had ravaged Italy and the Mediterranean - from the First Triumvirate of Gnaeus Pompeius Magnus, Julius Caesar and Marcus Licinius Crassus to the Second Triumvirate of Antony, Lepidus and Octavian (the future Augustus). A final round of civil wars ended at the Battle of Actium in $31 \mathrm{BCE}$ and with the deaths of Antony and Cleoptra in the following year. Augustus now dominated affairs and like others before him had set about reorganisation and reconciliation of the war torn world he ruled (Galinsky, 1996). Virgil and Augustus recognized that, in the words of Miller, the "nation's wounds of civil strife and moral degeneration could not be healed, that lasting peace could never come, until the nation's heart had been touched by a new patriotism, that is turned back to their old 
patriotism, through an awakened memory of their glorious past, through a renewed assurance of a more glorious future" (Miller, 1928, p. 28).

Indeed, to Virgil war wreaked havoc on civil society and ruthlessly slayed young men in their prime. While "Virgil's battles, however violently energetic, are meant to be depressing. The fighting is grim, bloody, and pitiless, like that in the Roman civil wars. Few ask quarter, and none are granted it" (MacKay, 1963, p. 161). As such, the Aeneid may be seen as "an answer to the cry of a world exhausted by decades of bloody warfare, a world which...longed for nothing so much as for peace" (Duckworth, 1945, p. 105). Beyond the fighting, on the other hand, the sweeping epic of Roman imperium is aligned with the gods and piety (Hahn, 1931). Notably, other contemporaries composed narratives on the mythological founding of Rome: "Virgil's description of early Rome is free from the pessimism, ambiguity, double meanings and the spirit of cultural degeneration that characterize the narratives of Propertius and Tibullus" (Papaioannou, 2003, p. 682).

Moreover, Roman imperial aims as expressed by Cicero in De Re Publica (54 BCE) and Augustus in the Res Gestae (14 AD) were to prosecute war expressly to achieve peace (pax) and prosperity (see Res Gestae, Book 3; Aeneid, Book XI, 851-853). As Cicero (54 BCE) posited: “...law provides that in undertaking, carrying on, and ending a war, justice and good faith shall be supreme" (trans. Keyes, 1928, p. 413). In this context, Stoic ethics was a practical and broadly accepted feature of Roman society because "stoic advocacy of selfdenying duty, of subordination, praebere se fato, was in tune with traditional Roman and Virgilian ideas and ideals: with pietas...the proper method of war involves dispassionate, rational bravery and employs judicious, rational mercy..." (Lyne, 1983, pp. 189-190). That

\footnotetext{
2 All primary quotes from Cicero's On the Republic (54 BCE) and On the Laws (52 BCE), (C.W. Keyes, Trans., 1928). Suffolk, England: St. Edmundsury Press. All Augustus quotes from the Res Gestae are from: Cooley, A. (2009), Res Gestae divi Augusti. Cambridge, England: Cambridge University Press. Hereafter, only page numbers will be cited.
} 
is, Augustus needed a cohesive Roman world view to remind his countrymen of their past triumphs and traditions, as well as to fortify their manifest destiny or fatum, which was ultimately channeled through the vision of Virgil (Hammond, 1933; Galinsky, 1996, p. 21). As Cicero (54 BCE) noted a generation earlier: "A people is not a collection of human beings brought together in a certain way, but an assemblage of people in large numbers associated in an agreement with respect to justice and a partnership for the common good" ((trans. Keyes, 1928, p. 65). It was Virgil, however, who would capture this resonating common Romanworld view in the Aenied and as has been noted Virgil's "success as a panegyrist is partly because he did believe in the value of what Augustus was doing” (West, 1994, p. 61).

Publius Virgilius Maro, hereafter Virgil, was born 15 October 70 BCE, in the northern Italian village of Andes, a town just outside the city of Mantova (known today as Mantua). After moving to Rome, Virgil gained the patronage of Maecenas, a wealthy aristocrat and political confidant of Augustus. Virgil gained a reputation as the preeminent poet of Rome with his Eclogues (42 BCE) and Georgics (29 BCE). Of note, Eclogues Book IV or the socalled "Messianic Eclogue" predicted the birth of a saviour and great leader:

Now the last age of Cumae's prophecy has come; The great succession of centuries is born afresh. Now too returns the Virgin, Saturn's rule returns; A new begetting now descends from heaven's height.

$O$ chaste Lucina, look with blessing on the boy Whose birth will end the iron race at last and raise A golden through the world: now your Apollo rules. And, Pollio, this glory enters time with you; Your consulship begins the march of the great months; With you to guide, if traces of our sin remain, They, nullified, will free the lands from lasting fear. He will receive the life divine, and see the gods Mingling with heroes, and himself be seen of them, And rule a world made peaceful by his father's virtues (Eclogues, Book IV, 4-17) 
Virgil was venerated by both pagans and later by Christians alike. The Roman world interpreted this prophecy as the coming of Augustus; and the Christian world subsequently, including Dante, heralded the passage as prophesizing the coming of Jesus Christ. While still under the patronage of Maecenas, Augustus turned to Virgil to deliver a cohesive national identity and manifest destiny of the Roman imperium (Hamilton, 1932; Galinsky, 1996; Holland, 2004). In this context Virgil "thought the evolution of his people's national identity was going through a particularly crucial formative phase, in which he aspired to make his poem participate. Thus he designed the Aeneid strategically to help the Romans meditate on the duties, problems, dangers, and possibilities of a new national identity" (Toll, 1997, p. 34).

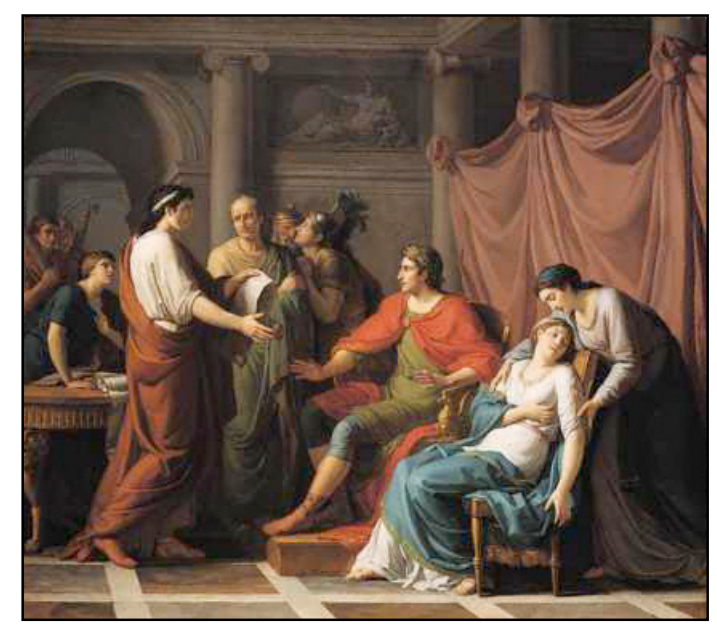

Figure 1: Virgil reading the Aeneid to Augustus and Octavia, 1787, by Jean-Joseph Taillasson

This thesis seeks to explore the following questions: Does modern context change the nature of effective leadership over time? Are there any fundamental human values that stand the test of time? Does values-based leadership answer the timeless need for leaders who are inherently Protean: able to adapt and respond to new circumstances as they arise (Ahn, Adamson \& Dornbusch, 2004). That is, instead of seeking a single, once-and-for-all solution, is leadership which fosters and manages a dynamic tension between focus and coordination, between the ongoing tasks of external and internal analysis (with its tendency to explode 
current expectations and assumptions), and the need to devise and implement responses to those findings in such a way that both utilizes most effectively - and also inspires the confidence and enthusiasm of - individuals and institutions still relevant? This study will review the Aeneid, the foundation work of the Latin cannon, in its historical context, code the themes of its key leadership lessons, employ a mixed-method research framework to juxtapose the leadership lessons identified to the demands of modern leadership, and provide implications for practioners and researchers. 


\section{Background of the Aeneid}

The Aeneid, which chronicles the story of Aeneas and his followers from their exodus after the fall of Troy to the founding of Rome, is composed of twelve books written in dactylic hexameter and was first published shortly after Virgil's death in 19 BCE. The hero Aeneas was already known to Greco-Roman legend and myth, having been a minor character in the Iliad who appears in several other myths and legends, both Greek and Latin, that provide the background material for the Aeneid. Virgil took the disconnected tales of Aeneas' wanderings, his vague association with the establishment of Rome, and shaped a profound national epic which established the founding myth of Rome and tied it to the legends of Troy and manifest destiny, glorified traditional Roman values which became the basis of sociopolitical reforms, and established unassailable legitimacy for the Augustan regime (Hammond, 1933). The carefully described journey of Aeneas accurately depicted the landmarks and paths between Naples and the Tyrrhenian sea that may still be followed to this day (Smiley, 1948) (see Figure 2). The first five of the poem's twelve books tell the story of Aeneas' wanderings from Troy to Italy (the Odyssey of Aeneas), and the poem's last six books chronicle the Trojans' ultimately victorious war upon the Latins (the Aeneid's Iliad), under whose name Aeneas and his Trojan followers are destined to be subsumed (for introduction and discussion see Gransden 1984 and 1990). 


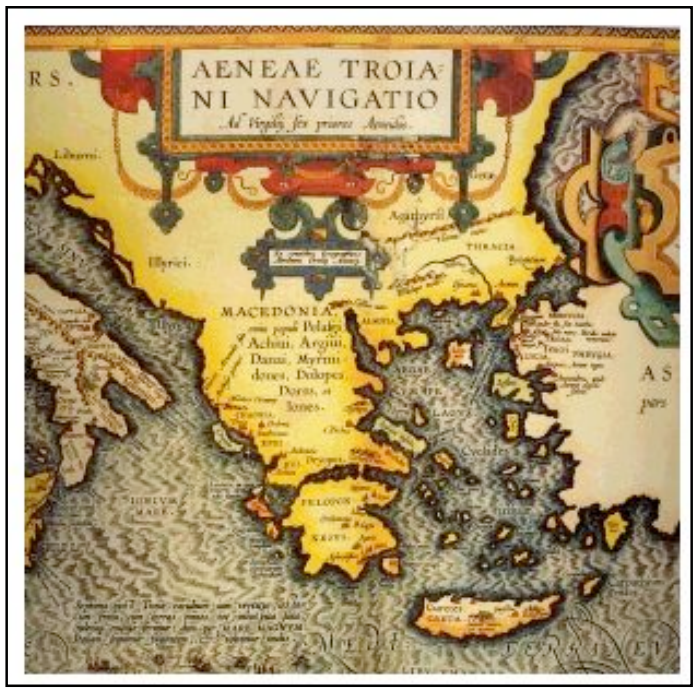

Figure 2: Map of the journey of Aeneas from Troy throughout the Mediterranean to Latium from an early copy of The Aeneid. Source: http://ancientcoinsforeducation.org.

\subsection{The Aeneid from a Leadership Lens}

One of the principal themes of the Aeneid is the way in which the Trojans are transformed from losers at Troy to winners in Italy and in that process from Trojans into Romans. The same is true for Aeneas as he transforms from a minor prince at Troy to the leader of the Trojans and ultimate victor in Italy. Aeneas literally sheds the past, leaving behind his king (Priam), wife (Creusa), and father (Anchises), as he emerges as a confident king, father and commander in his own right. From a leadership lens, Virgil endows Aeneas with human qualities, portraying him as a heroic yet flawed mortal man who overcomes his doubts and setbacks to ultimately realise his fate. Within the genre of epic poetry, one of the more unique and innovative conventions developed by Virgil was to allow Aeneas to transform from an indecisive, self-doubting victim of circumstance, literally driven by Fate (Aeneid, Book I) commanded by others (like Anchises in Book 3). This transformation is well illustrated in his diversion to Carthage and his soul-searching emotional decisions as to whether or not he 
should remain with Dido, into a supremely confident, charismatic leader who selflessly risks single combat with Turnus to spare others suffering (see Fuhrer, 1989). That is, the leadership effectiveness of Aeneas grows greater as his responsibilities grow and he "comes in the end to accept freely the terrible burden placed on him by destiny; and who at last shakes off the Trojan past to face the Roman future" Dudley (1961, p. 53). Further, Aeneas' gravitas and dignitas, his public and private integrity, suffer severe setbacks, but his virtus and pietas allow him to align himself with the gods and fulfill his destiny (Hahn, 1931; Earl, 1967; McLeish, 1972).

As MacKay (1963) posited, the Aeneid represents "Virgil's comment on the human condition: that great leaders are necessary, but that they have a bit of the scoundrel in them; he can appreciate their admirable qualities without shutting their eyes to their unlovable qualities, and he is not sentimental enough to make their failings lovable failings. We are meant to be shocked—shocked into opening our eyes" (p. 165). In Book I, for example, he experiences overwhelming grief when he cannot find his wife Creusa during the fall of Troy and he feels discouragement when his fleet is struck by a storm. In Book II, Aeneas is uncertain about the course of action he should take. Later in Book IV, Aeneas is torn between his love for Dido and his need to fulfill his mission. In Book XII, he gives in to his passion and thirst for revenge as he dispatches a fallen Turnus. Throughout the Aeneid, we see Aeneas as a sensitive, compassionate man who is sympathetic and loving towards his people - yet devout and steadfast to his manifest destiny or fatum.

Aeneas' humanity and struggles make his character both accessible and timeless. His audience, whether ancient Roman or modern, transform with him and overhear themselves reexamining their own actions - which is the persuasive aim of rhetoric. We have noted the need for such a national poem in the Augustan moment and as Bloom (2002) stated: "The 
emperor Augustus needed the poem because it gave his era an idea of order and greatness, an achieved foundation of authority; Aeneas always looked towards the future, to the rise of a new Troy in Rome, which will end exile and inaugurate justice" (p. 76). In other words, by virtuous actions one becomes closer to the gods (Galinsky, 1996). Cicero (52 B.C) saw this when he stated that "virtue exists in man and God alike, but in no other creature besides; virtue, however, is nothing else than Nature perfected and developed to its highest point; therefore there is a likeness between man and God" (trans. Keyes, 1928, p. 325). Modern readers too can see in the Aeneid significant resonance. Human frailty can overcome divine challenges and still, as the ending of the poem recognises with the killing of Turnus in an act of Furor, remain flawed.

The Aeneid cannot disguise the fatum or destiny of Aeneas and the inevitable founding of Rome. Augustan readers (like those of our own day) knew well that Aeneas would succeed in his mission. Vergil highlights the inevitable future several times in the poem (most obviously see Book VI, 790-6 and Book VIII, 678-90). As early as Book I (278-279) we, along with Aeneas' mother Venus, are reassured of the outcome. Thus another important issue that seems at odds with the practice of human leadership making a difference is the role of fate and the role of the gods. That is, does leadership matter at all since the gods have preordained the outcome? The answer to this dichotomy may be found in the tradition of using the anthropomorphic gods to align behaviour towards a socio-political agenda via pax deorum. As Tracy (1964) deconstructed the role of fatum in the Aeneid: "What gives fate its formidable aspect is not power or purpose, but simply its inscrutability" (p. 190). That is, the gods in the Aeneid are a "... way of portraying a divine presence in human affairs... Men may come to harm through ignorance, neglect or contempt of the divine plan but there is no place for supplications or placatory offerings" (Coleman, 1982, p. 144). In this context, Virgil is 
"genuinely a spokesman for the religious "reforms" of Augustus... and that neglect of these gods was at least one explanation for the wars of republican Rome" (Korfmacher, 1956, p. 334). As Cicero in De Legibus (On the Laws) in 52 BCE noted, the essence of leaders being in alignment with the gods is self-knowledge:

Wisdom is the mother of all good things...to all other wisdom, that most difficult of all things - to know ourselves...For he who knows himself will realize, in the first place, that he has a divine element within him, and will think of his own inner nature as a kind of consecrated image of God; and so he will always act and think in a way worthy of so great a gift of the gods (trans. Keyes, 1928, p. 61).

In extolling the piety of the past and invoking a manifest destiny of the "golden age" of the future, this outlook conforms to a worldview whereby Romans were encouraged to think of themselves as descendants of Troy which reinforced not only their right, but also their responsibility, to conquer and lead world civilization (Holland, 2004). McGushin (1964) suggested that linking the Aeneid to mythology generally, and endurance or hardness (Atlas) specifically, calls upon Romans to have endurance as "the supreme quality...which supports the sky and stands firm against the attacks of nature" (p. 227). In more prosaic terms "the victory of labor over amor, Aeneas over Turnus, is also a victory of Augustan ideology" (McDonald, 1972, p. 48). From this perspective, the role of the gods - as conceived by man - is to deftly require individual sacrifice and social order through endurance akin to the mythological giant shoulders of Atlas. Thus, Edwards (1960) wrote that:

The sufferings which fall upon so many of the characters in the Aeneid, including Aeneas himself, are brought about by their human feelings, but these are regarded not as weaknesses, not with the Stoic's rejection of the emotions, but as pathetic and often admirable traits of human nature; and the conflict which makes the tragedy of the Aeneid is not that of the naked clash of moira with heimarmene but that of the facts of human nature with the facts of human existence, of natural human feelings with the inhuman and invincible force of circumstance (p. 160).

Moreover, endurance in this context may be seen as extolling the four cardinal leadership virtues of the prevailing Greco-Roman philosophy derived from the teachings of Plato: 
wisdom, courage, justice, and temperance (Bowra, 1933). From the outset, Aeneas and his followers are beset with challenges that, despite their misgivings and devastating losses, must hold themselves together to progress. In Book I, for example, the Trojans land near Carthage having fled from the Trojan War seven years prior. Aeneas and his followers are sailing to Italy to establish a new home when Juno, queen of the gods and arch-enemy of the Trojans, has Aeolus, god of the winds, blow up a violent storm that separates the Trojan Fleet and also drives their ships off course. Aeneas, with only part of his fleet, lands in North Africa.

A man apart, devoted to his mission-

To undergo so many perilous days

And enter on so many trials...

They wandered as their destiny drove them on

From one sea to the next: so hard and huge

A task it was to found the Roman people (Book I, 16-18; 47-49).

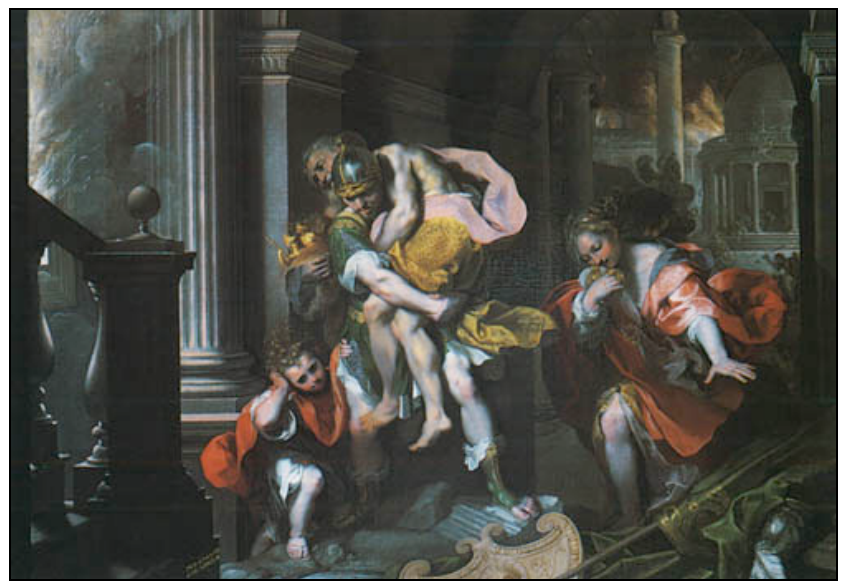

Figure 3. Aeneas, Anchises, and Ascanius Fleeing Troy, 1596, by Federico Barocci.

Thus, Virgil's use of the role of the gods may be seen as conferring a divine blessing and even divinity as the reward of endurance and effort — as well as the poet's view of Augustus as the Princeps and his role in the history of Rome (Hammond, 1933). Romans would have identified with this well. As Cicero (54 BCE) noted: “...your duty will be to hold up before the fatherland the light of your character, your ability and your wisdom... all those who have 
preserved, aided or enlarged their fatherland have a special place prepared for them in the heavens" (trans. Keyes, 1928, p. 13). McGushin (1964) encapsulates these ideas of endurance when he states: "Virgil's coupling of Augustus with the role and destiny of Aeneas, the controlling idea of the epic, is to stress the theme of labour and endurance, the fruits of which are to be city and empire and, in the long run, a place among the gods" ( $\mathrm{p}$. 245). From one perspective, Rome itself, rather than Aeneas is the central character of the epic. Other modern scholars extol the virtues of the individual leader in the epic. Morwood (1998) notes that, "Augustus the builder is one of the great heroes of the Aeneid. It is in him that the themes of city and builder become one" (p. 221), while Bell (1999) saw that the Aeneid must be contextualized as a communication vehicle in public venues and influential houses of Rome where: "Virgil's artistry succeeded not only in pleasing the community at large but thereby also in communicating aesthetically a regime's legitimacy" (p. 263). The point is that Aeneas still has to perform as the ideal leader in order to succeed in the poem, despite the overarching role of destiny in the poem's (and history's) ultimate conclusion. If Aeneas were not the ideal leader then his fatum, that thing which drives him from the start would not mean anything and would certainly not amount to anything. Both Aeneas and Augustus are connected, and their respective successes come to be inevitably founded on their own perfect leadership qualities, in what can only be seen as self-fulfilling destiny. Without the humans there is no story and certainly no foundation of an imperial Augustan Rome.

\subsection{Values-Based Leadership and the Aeneid}

While the Aeneid has been explored from many and varied literary, cultural and historical perspectives (see Galinsky, 1996), this thesis seeks to explore Virgil's work from a values- 
based leadership perspective. While leadership theories and definitions proliferate, the following definition is adopted: "leadership over human beings is exercised when persons with certain motives and purposes mobilize, in competition or conflict with others, institutional, political, psychological, and other resources so as to arouse, engage, and satisfy the needs of followers" (MacGregor Burns, 1978). Building on this construct, values-based leadership is defined as the moral foundation underlying stewardship decisions and actions of leaders (O’Toole, 1995).

The central premise parallels modern understandings within emotional and social intelligences, stewardship, and servant leadership (Goleman, 1998; 2006; Boyatzis \& McKee, 2005). As MacKay (1963) noted in this context, Virgil "created an imaginative study of the moral dilemma of men and societies in a universe that often seems indifferent or even hostile to moral action" (p. 166). The focus of leadership studies, however, is not to define leadership, but to explore: "What is good leadership? The use of the word good here has two senses, morally good or technically good or effective... The question of what constitutes a good leader lies at the heart of the public debate on leadership" (Ciulla, 1998, p. 13).

Indeed, a driving theme of the Aeneid is an examination of the role of leaders in pursuing selfish personal happiness versus virtuous civic responsibility which is exactly the opposite relative to Odysseus in the Odyssey, whereby his followers must perish for him to regain his own status. The narrative of the Odyssey is from the perspective of one man (Odysseus) versus all. The opposite is true of the Aeneid in which Aeneas is the leader of an all for one community in order for it to survive and to prosper. As Hahn (1931) noted: "Aeneas is human enough to be tempted, and great is his provocation; but we must be thankful that he does not fall" (p. 13). His success promotes the success of the group. In fact, the development of Aeneas' virtus or values is a central tension throughout the narrative as "the accepted story of 
Aeneas would not hold together-granted that Aeneas was the founder, the patron saint of Rome-unless he was shown as a man faithful to a mission, but denied the revelation of his purposes except through slow, puzzling, and dark hints, often negative, or corrective only after grievous error had been committed. It took a special kind of virtue to be faithful to such a mission" (Tracy, 1964, p. 195).

This view of tension in values resonates with the challenges of modern leadership. Despite their widely varied contexts throughout time, a common basis on which leaders are consistently evaluated, and embraced or rejected are their values. Recent studies have explored the role of values-based leadership in terms of the organisational leader establishing ethics and values to enhance influence over followers, as well as how forms of leadership styles will develop organisational momentum and cohesion (MacGregor Burns, 1978; Russell, 2000; Riccucci \& Getha-Taylor, 2009).

Transformational and charismatic leadership have been raised as potential styles of leadership in order to establish a values-based perspective, and have been found to be positively correlated to each other (Garg \& Krishnan, 2003). The paradigm of modern transformational leadership was started by MacGregor Burns (1978) who posited that a leader needs to motivate, encourage and induce people to be aware of how they feel and take purposeful action to achieve desirable end-states. Transformational and charismatic approaches to leadership develop the relationship between leader and follower beyond transactional exchanges. Both approaches aim to use intrinsic motivation to inspire individuals to work beyond personal interests and towards collective goals for the organisation (Grojean, Resick, Dickson \& Smith, 2004). As Bass (1998) noted:

Leaders are truly transformational when they increase awareness of what is right, good, important, and beautiful; when they help to elevate followers' needs for achievement and self-actualization; when they foster in followers higher moral maturity; and when they 
move followers to go beyond their self-interests for the good of their group, organization, or society (p. 171).

The exercise of leadership is intimately linked to personal, social, and institutional culture and value understandings. Whether in business, government, or non-profit settings, building well-managed, high performing organisations are critical to creating value, accelerating economic development, and addressing pressing social issues. While recent headlines have placed the focus of governance on controls and fiduciary oversight (e.g., Cadbury Report of 1992 in the United Kingdom, Rapport Vienot of 1995 in France, KonTrag of 1998 in Germany, Sarbanes-Oxley Act of 2002 in the U.S. were all responses to public outcries over scandals in large, theretofore successful companies such as Enron, Worldcom, and Tyco), the more prosaic and primary role of governance in increasing the sustainability and enhancing the performance of organizations is often overlooked. As Paine (1994) noted:

Rarely do the character flaws of a lone actor fully explain corporate misconduct. More typically, unethical business practice involves the tacit, if not explicit, cooperation of others and reflects the values, attitudes, beliefs, language, and behavioral patterns that define an organization's operating culture. Ethics, then, is as much an organizational issue as a personal issue (p. 106).

That is, values at the organisational level of analysis are based upon the belief that companies need both "private" and "public" capital to survive and prosper. In this view, "private" is the resources invested and reinvested from earnings by the owners. "Public" or social capital is the goodwill and support that the enterprise receives from its fellow citizens (e.g., employees, local communities, customers). These groups are sometimes also called stakeholders" (Berenbeim, 2004).

Notwithstanding, given the pressure and immediacy of modern demands, there can be a tendency to be believe that the "prevailing" challenge or crisis at hand is fundamentally different than all others in the past. From one perspective, some leadership experts have 
asserted that lessons from the past have little to offer contemporary leaders in a modern world of information overload, high-speed communications, and global capital markets driving interdependence:

The leadership models of the past provide little guidance for the business context of the future...Many factors are transforming the context of leadership today: globalization and technological change lead to heightened competition, which in turn leads to new organizational models. The emergence of a knowledge-based workforce, so varied and different from its predecessors, places a relentless emphasis on innovation, adaptability and collaboration. Information technology offers new working practices, but demands new strategies. These chaotic changes are leading to an ever-more complex business environment, full of leadership challenges (Accenture, 2001, p. 1).

Further, other critics even have questioned the value of studying the humanities in preparing for professional careers and enhancing national competitiveness, as Kronman (2007) chronicled in “Education's End: Why Our Colleges and Universities Have Given Up on the Meaning of Life".

A competing perspective, however, is that the perennial leadership challenge for governing our institutions remains constant from antiquity to today: to build the good society which balances the necessity of tension between liberty, equality, community and efficiency (O’Toole, 1995). In this context, the palette of epic poetry generally, and the Aeneid specifically, provides a useful lens to imaginatively examine timeless opportunities and tensions as "poetry asks for accountability to a human community, for rootedness and responsibility even as it changes" (Whyte, 1994, p. 10). As Cicero noted in De Re Publica (54 B.C), "salus populi suprema est lex...quid est enim civitas nisi iuris societas? (the welfare of the people is the ultimate law... [and] for what is a State except an association or partnership in justice)" (trans. Keyes, 1928). In other words, governance necessarily requires moral judgment on the part of decision makers. In this context, it is important to study the Aeneid as "a war-poem of antiquity and distinction, and to find how correct according to it 
the manuals and the instructors-at-arms are; also incidentally to find how some of the techniques regarded as ultra-modern are hoary with age in reality" (Alexander, 1945, p. 261). As Augustus aspired:

May it be my privilege to have the happiness of establishing the commonwealth on a firm and secure basis and thus enjoy the reward which I desire, but only if I may be called the author of the best possible government; and bear with me the hope when I die that the foundations which I have laid for its future government, will stand firm and stable (trans. trans. Thompson, 2007, p. 324).

Thus, the exercise of leadership in the broader context of governance (e.g., stakeholder engagement, vision, execution) can have a powerful and sustainable impact on organisational performance and value. Greek literature and Roman epic differ then in this regard. In this context, Virgil no doubt intentionally juxtaposes Aeneas to Odysseus in the Odyssey. Greek tragedy also highlights the role and flaws of the individual. Tracy (1964) identified that "whereas in Greek Tragedy we see the fall of the hero inherent in his prosperity and pride, in reading the Aeneid amid the frustration and exasperation we see always the promise of fulfillment" (p. 195). Further, the theme of individualism of the Greeks versus the collective Roman imperium is juxtaposed throughout the epic and would have been readily recognized by Virgil's contemporary Roman audience. For example, Aeneas is a normative prototype in that he speaks far less than his Homeric predecessors (18 percent of lines in the Odyssey are spoken by Odysseus; 13 percent by Achilles in the Iliad; and only 6 percent by Aeneas in the Aeneid) (Galinsky, 1996, p. 344).

These differences also have practical manifestations which support the stability of power structures. For example, the Greek practice of not separating political power from the individual versus the Roman practice of viewing an office as continuous and indivisible, no matter how many individuals occupied it (Hammond, 1933). Thus, contextual ideals and ideas about leadership laid the foundations for both Homer and Virgil's conceptions of their 
heroes as leaders. In this way the Aeneid reflected Roman attitudes and customs concerning leadership, and we can see Aeneas as a manifestation of one type of perfect leader. As Cicero (54 B.C) presaged “...our own commonwealth was based on the genius, not of one man, but of many; it was founded, not in one generation, but in a long period of several centuries and many ages of men (trans. Keyes, 1928, p. 113).

Moreover, the sustainability and legitimacy of effective governance can only be maintained within the context of values-based leadership for all stakeholders. History, or at the very least its memory and narrative, has shown that disastrous consequences can occur when leaders stray from these lessons, letting power and self-interest override fundamental human values. In other words, transformational leadership stands in stark contrast to charismatic amoral leaders such as Pol Pot, Hitler, Stalin, Sptizer, Skilling, Madoff, and many others who sought magnificence at the expense of others. Their lessons of life were reframed for maniacal purposes resulting in societal and human tragedy (i.e., "the bad king"). As Cicero in De Legibus (52 BCE) observed, "if it be true that virtue is sought for the sake of other benefits and not for its own sake, there will only be one virtue, which will most properly be called a vice (trans. Keyes, 1928, p. 351).

This thesis will juxtapose the resonant leadership elements of vision, culture and valuesand applying their corresponding equivalent Roman themes as fatum, pietas, and virtusfound in the Aeneid to the demands of modern leadership to provide leadership insights and support practical contemporary relevance of the epic (Figure 4). 


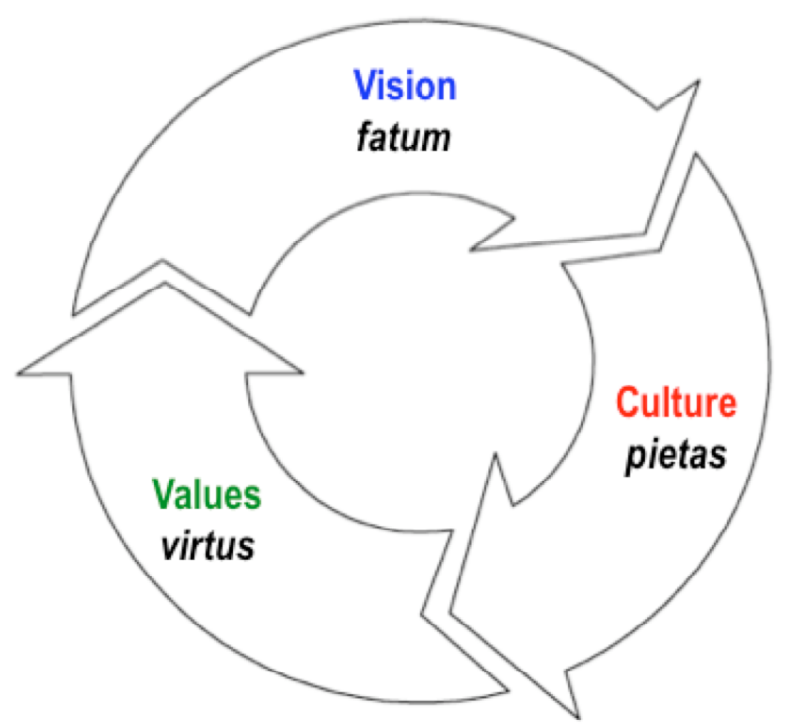

Figure 4: Leadership Elements and Roman Themes in the Aeneid

While the Aeneid was important in its historical role as a communication tool to encourage and extol virtus or virtuous behaviours which would support the growth, peace and prosperity of what would become the Pax Romana or golden age of the Roman imperium, this thesis seeks to explore the question: What is the relevance of the Aeneid to modern leaders? In the next section, the Aeneid will be coded for key leadership themes which will then be tested for relevance relative to a diverse, cross-sectoral (i.e., for profit, non-profit, government) set of modern leaders. 


\section{Methodology \& Values-Based Leadership Themes}

\subsection{Methodology}

A mixed-method research framework or triangulated design (Jick, 1979; Yin, 1984; Sackett \& Larson, 1990; Scandura \& Williams, 2000) was employed to explore the relevance of lessons from the Aeneid to the demands of modern leadership. This framework uses multiple approaches to investigate the research question to increase the rigor and relevance of the study. Using a social systems approach (Wren \& Swatez, 1995), values can be explored to deconstruct the complex network of tensions which "recognizes that the leadership process is a complex, multifacted network of forces..."(p. 247). Using this approach, key leadership dimensions and lessons from the Aeneid were grouped into three major categories: vision (fatum), culture (pietas), and values (virtus).

Utilising the principles of thematic analysis (Boyatzis, 1998; Auerbach \& Silverstein, 2000; Braun \& Clarke, 2006), arching themes were explicated from interviews with a diverse group of multi-sectoral leaders. Thematic analysis is a systematic process for fracturing, reorganizing and categorising the content of text and identifying relationships among data (Berg, 1995; Maxwell, 1996) that promotes the collection and use of qualitative information in a manner which facilitates communication with a broad audience (Boyatzis, 1998), and is regularly used by scholars and researchers in literature, psychology, sociology, cultural anthropology, history, art, political science, economics, mathematics, chemistry, physics, biology, astronomy, and many other fields (Crabtree \& Miller, 1992; Denzin \& Lincoln, 1994; Marshall \& Rossman, 1989; Silverman 1993). In other words, thematic analysis is a process of encoding qualitative data, which involves developing an explicit code and the identification of patterns within the information (Boyatzis, 1998; Crabtree \& Miller, 1999). 
In this case, deductive thematic analysis (Crabtree \& Miller, 1999; Braun \& Clarke, 2006) was utilised to examine key themes from responses of 13 high-ranking leaders (e.g., managing director, chief executive, judge, et al) to 11 open-ended questions on vision, culture, and values-based leadership. Thematic comparisons between types of respondents were also analysed to identify patterns of response by sector (i.e., for profit, non-profit, government). The thematic analysis proceeded in six stages. First, the Aeneid was coded to identify manifest and latent themes that emerged from Virgil's primary vision (Fitzgerald, 1981) and critical reviews of the text (for example, see: Hahn, 1931; Bowra, 1933; Smiley, 1948; Wilson, 1969; Cairns, 1989; Toll, 1997; Bell, 1999). Second, insights were coded at a meta-level to identify over-arching themes. Third, the data were coded based on the valuesbased leadership literature (O’Toole, 1995; Maxwell, 1996; Garg \& Krishnan, 2003; Conchie, 2004; Majer, 2005; Van Lee, Fabish \& McGaw, 2005). Fourth, the identified codes were grouped into themes. Fifth, the themes were transformed into eleven interview questions (please see Appendix A). Sixth, the themes were presented to researchers and leaders who evaluated the interview questions for plausibility and face-validity, with any discrepancies resolved through discussion.

Thus, in this study triangulation involved anonymized qualitative and quantitative interviews of leaders across a diverse multi-sectoral spectrum (e.g., business, military, religious, political, academia). Open-ended, unstructured interviews have been shown to work best when interviewing influential thought leaders and experts (Yin, 1989). The next section reviews each of the key values-based leadership themes identified in coding the Aeneid, which is then followed by a quantitative and qualitative analysis of the themes to the demands of modern leadership. 


\subsection{Key Values-Based Leadership Themes}

\section{$\underline{\text { Vision }}$}

A compelling vision, larger than any individual, is necessary for organisational success and sustainability. Virgil uses fatum to "justify the ways of God to men" and establish the divine providence through which the mighty Roman imperium "was to be established in the world to show [the] great, foreordained mission of [the] nation" (Miller, 1928, p. 29). Aeneas' steadfast vision to found a new home and opportunity for peace and prosperity for his displaced people of Troy, while overcoming a series of obstacles and making great personal sacrifices, is an arching theme throughout the epic:

A man apart, devoted to his mission-

To undergo so many perilous days

And enter so many trials...For years

They wandered as their destiny drove them on

From one sea to the next: so hard and huge

A task that was to found the Roman people

(Book I, 16-18, 46-49)

Vision requires imagination, courage and fortitude precisely because it is an envisioned future and requires change from the status quo. Aeneas' "Rome does not exist, but even so he has to show what it is like to be Roman. He needs to display dogged selfless endurance... Rome is not a real city of bricks and mortar, but a state of mind" (Morwood, 1991). Ultimately, Aeneas "obeys his fate, knowingly and willingly...above all he shows pietas by scrupulousness in consulting and obeying the gods" (Hahn, 1931, p. 665).

Notwithstanding, the exercise of fatum requires maximum effort and stoic virtues because as "strongly as Fate broods over the whole action, its power is not directly or practically exercised in detail, and its divine agents are pictured as inconsistent and confused administrators. Fate is more like a musical theme in the Aeneid than an organic part of the story" (Tracy, 1964, p. 194). Even when Aeneas is tempted to break with his destiny, he 
finds the strength to remain pious and committed to an envisioned future much larger than himself:

If future history's glories

Do not affect you, if you will not strive

For your own honor, think of Ascanius,

Think of the expectations of your heir,

Ilus, to whom the Italian realm, the land

Of Rome, are due...

As the sharp admonition and command

From heaven had shaken him awake, he now

Burned only to be gone (Book IV, 370-375; 382-384)

To fulfill his manifest destiny:

...from his quarters Lord Aeneas came-

The father of the Roman race-aglow

With starry shield and armor forged by heaven (Book XII, 224-225)

By comparison in the political realm, Augustus summarizes his relentless vision or fatum

of Roman manifest destiny in his funerary inscription, the Res Gestae (14 AD):

I extended the boundaries of all the provinces which were bordered by races not yet subject to our empire. The provinces of the Gauls, the Spains, and Germany, bounded by the ocean from Gades to the mouth of the Elbe, I reduced to a state of peace. The Alps, from the region which lies nearest to the Adriatic as far as the Tuscan Sea, I brought to a state of peace without waging on any tribe an unjust war. My fleet sailed from the mouth of the Rhine eastward as far as the lands of the Cimbri to which, up to that time, no Roman had ever penetrated either by land or by sea, and the Cimbri and Charydes and Semnones and other peoples of the Germans of that same region through their envoys sought my friendship and that of the Roman people (trans. Cooley, 2009, p. 90).

Virgil's Eclogues (42 BCE) set forth the enduring visionary ideal that "we are all Roman", which continues to echo in modern governance with novus ordo seclorum (new order of the ages) which was adopted on the Great Seal of the United States since 1782; and has appeared on the back of the US dollar since 1935 (see Figure 5):

Now comes the final era of the Sibyl's song;

The great order of the ages is born afresh.

And now justice returns, honored rules return;

now a new lineage is sent down from high heaven (Book IV, 5-8). 


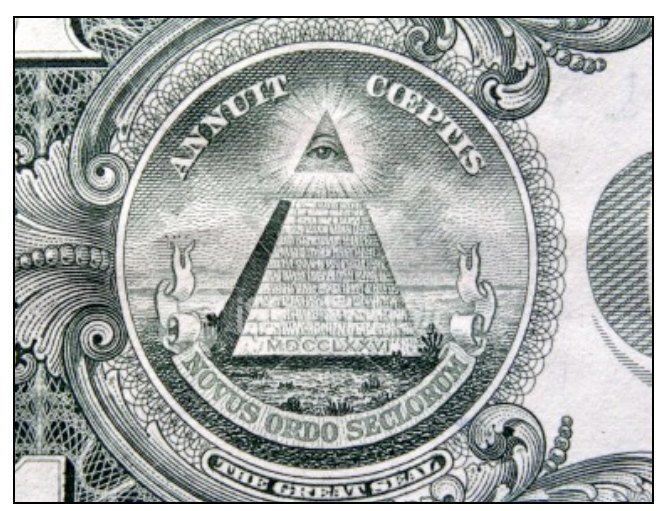

Figure 5: Great Seal of the United States of America denoting
novus ordo seclorum (new order of the ages) from the Eclogues

Consistent with this perspective, a broad review of historical contexts concluded that "no society has ever flourished without a spiritual mission; the quest for material progress alone is insufficient to spur men on to the achievements which are required to create an enduring, dynamic, progressive nation. In fact, [the] conclusion is that all through history material progress as a national goal has led to stagnation, boredom, and moral decay" (Learned, Dooley \& Katz, 1959, p. 113).

From a modern leadership lens, establishing a clear and compelling vision is a distinguishing characteristic of successful organisations throughout history from proscribed manifest destiny (Quint, 1989) to prosaic modern leadership studies (Gouillart \& Kelly, 1995; Kay, 1995; Collins \& Porras, 1996). As Senge (1990) noted, "if any one idea about leadership has inspired organizations for thousands of years, it's the capacity to hold a shared picture of the future we seek to create" (p. 9). An organisation's vision may be characterized as what a firm will become if it successfully and repeatedly completes its mission (Thomas, 1993). Collins and Porras (1996) have noted that "to create an effective envisioned future requires a certain level of unreasonable confidence and commitment” (p. 75).

Marmol and Murray (1995) found, in a study of ten companies during the late 1970s to 
early 1990s, that each successful firm had a leader with extraordinary (to seemingly unreasonable) performance aspirations. As an example, Cisco Systems became the global leader in network computing with $\$ 36$ billion in 2009 revenues principally through acquisitions and attendant integration risk, despite overwhelming empirical evidence that 6080 percent of mergers fail (Tetenbaum, 1999). Their clear mission has kept the company focused on building on their core strength: "Cisco hardware, software, and service offerings are used to create the Internet solutions that make networks possible-providing easy access to information anywhere, at any time." Vision statements also work across sectors. NASA (National Aeronautics and Space Administration), for example, provides a succinct and compelling vision statement: "To improve life here, To extend life to there, To find life beyond."

Articulating a vision of the future, however, is only a first step in an enabling organisational commitment. Kotter (1996) found that firms which fail to produce successful organisational change often underestimate the power of vision, undercommunicate the company's vision, and permit obstacles to block the new vision. These impediments may be characterized as failures to effectively build and communicate an organisation's shared vision. As Gini (1998) noted "leadership is a power- and value-laden relationship between leaders and followers/constituents who intend real changes that reflect their mutual purposes and goals" (p. 35). Thus, the first hypothesis $(\mathrm{H})$ is:

H1: A compelling vision, larger than any individual, is necessary for organizational success and sustainability. 


\section{Culture}

The Aeneid may also be interpreted as a conscious attempt to shape the socio-political discourse and cultural norms of Rome. Political power and cultural creativity are not often related, but the age of Augustus was intrinsically different (Galinsky,1996). The "poem not only helped to cast Augustus' seemingly inevitable power as heroic but also to make that heroic power comprehensible in the contemporary idioms of communication in the Res Publica...[who] would have had little difficulty in understanding the roles of Aeneas and Augustus, the two heroic leaders positioned at the opposite poles of the fated trajectory of the national history" (Bell, 1999, p. 264). Jupiter ordained their destiny from the Fall of Troy to the founding of Rome and the promise of an empire without end:

In Italy he [Aeneas] will fight a massive war, Beat down fierce armies, then for the people there Establish city walls and a way of life... But the boy, Ascanius, to whom the name of Ilium stood...

He will transfer his capital from Lavinium and make A fortress, Alba Longa. Three full centuries That kingdom will be ruled by Hector's race, Until the queen and priestess, Ilia, Pregnant by Mars, will bear twin sons to him. Afterward, happy in the tawny pelt His nurse, the she-wolf, wears, young Romulus Will take leadership, build walls of Mars, And call by his own name his people Romans. For these I set no limits, world or time, But make the gift of empire without end. (Book I, 355-375)

By comparison, Augustus in the Res Gestae and his other political propaganda emphasized that his political actions were wholly consistent with traditional Roman values which, if adhered to, would provide the basis for sustainable imperial growth and prosperity:

By the passage of new laws I restored many traditions of our ancestors which were then falling into disuse, and I myself set precedents in many things for posterity to imitate (trans. Cooley, 2009, p. 66). 
A critical aspect of Augustan policy was shaping culture and behavioural norms, and avoiding insidious practices which could undermine social stability. A resonating symbol is Virgil's monstrum allegory whose eyes, tongues and mouth represent the "human character of gossip in its real vulgarity and power. Just as there were eyes vigilant for subjects of gossip so there are ears ready to listen to the mouths which report it...relating the power of gossip to destroy with the numbers of human eyes, tongues, mouths and ears which engage in it" (Dyer, 1989, p. 30-31).

In the context of modern leadership, globalization and increasing communications capabilities requires faster decision-making to maximize competitive capacity. Faster decision-making also drives increasing rates of empowerment throughout the organisation. Thus, a major challenge facing the firm is: How do we coordinate and align actions toward a common vision in an environment of distributed decision-making (Ahn, Adams \& Dornbusch, 2004)?

Corporate culture, which refers to norms of behavior and shared values among a group, anchors distributed decision-making, and allows the firm to direct behaviors towards a common vision. Corporate culture manifests itself in powerful, shared values which shape group behavior and persists despite changes in group membership. Kotter (1996) found that corporate culture strongly influences performance because culture provides selection criteria for hiring and indoctrination, exerts itself through the actions of nearly all employees continuously, and influences behaviour without conscious intent:

In the twentieth century, we have found group norms and shared values in organizations mostly to be barriers to change. They don't need to be. Cultures can facilitate adaptation if they value performing well for an organization's constituencies, if they really support competent leadership and management, if they encourage teamwork at the top, and if they demand a minimum of layers, bureaucracies and interdependencies ( $p$. 170). 
Organisational culture and climate are also social settings that affect new and current employees (Kopelman, Brief \& Guzzo, 1990). Organisational climate refers to employees' shared perceptions of organisational practices which provide a benchmark of institutionalised normative behaviour (Grojean, Resick, Dickson \& Smith, 2004). Culture is an integral part of the entire organisational landscape. Values contribute extensively to the establishment of organisational culture, and thus influence the way individuals behave within the social environment. According to Schneider (1975), an organisational climate is a psychologically meaningful environment with the potential to shape social norms, expectations, and appropriate behaviour in a particular setting.

At the organizational level, culture shapes a company's reputation and reflects a customer's predisposition that a company's product and/or brand will live up to its claim. Fombrun (1996) found that companies with excellent reputations: command premium prices for their products, pay lower prices for purchases, entice top recruits to apply for positions, experience greater loyalty from consumers and employees, have more stable revenues, face fewer risks of crisis, and are given greater latitude to act by their constituents (see Table 1). In 2009, the top 10 most admired companies according to Fortune magazine were: Apple, Walt Disney, Google, Nike, Medco Health Solutions, Herman Miller, Amazon.com, Goldman Sachs Group, Integrys Energy Group and Graybar Electric. 


Constituency
\begin{tabular}{|l|l|l|}
\hline \multirow{4}{*}{ Employees } & 1. Generate Trust & \multicolumn{1}{c|}{ Images } \\
& 2. Empower & Trustworthiness \\
& 3. Instill Pride & \\
& 4. Show Profitability & \\
\hline Investors & 5. Maintain Stability & Credibility \\
& 6. Have Growth Prospects & \\
\hline Customers & 7. Cultivate Product Quality & Reliability \\
& 8. Provide Customer Service & \\
\hline Community & 9. Serve the Community & Responsibility \\
& 10. Green the Environment & \\
\hline
\end{tabular}

Table 1: Corporate Practices and Images.

Source: Adapted from Fombrun (1996)

Most large companies have codified their value systems to align corporate culture and provide a benchmark for behavior. For example, nurturing a values-based corporate culture has been critical to the success and sustainability of Johnson \& Johnson (J\&J). General Robert Wood Johnson, former chairman from 1932 to 1963 and a member of the Company's founding family, crafted Our Credo himself in 1943, just before J\&J became a publicly traded company. Long before the term "corporate social responsibility" was popularized, Our Credo was created as a one-page document to outline the operating principles that continue to guide the company decades later (Figure 6). 


\section{Gohnsonatfohnson}

Our Credo

We believe our first responsibility is to the doctors, nurses and patients, to mothers and fathers and all others who use our products and services.

In meeting their needs everything we do must be of high quality.

We must constantly strive to reduce our costs

in order to maintain reasonable prices.

Customers' orders must be serviced promptly and accurately.

Our suppliers and distributors must have an opportunity to make a fair profit.

We are responsible to our employees,

the men and women who work with us throughout the world.

Everyone must be considered as an individual.

We must respect their dignity and recognize their merit.

They must have a sense of security in their jobs.

Compensation must be fair and adequate,

and working conditions clean, orderly and safe.

We must be mindful of ways to help our employees fulfill their family responsibilities.

Employees must feel free to make suggestions and complaints.

There must be equal opportunity for employment, development

and advancement for those qualified.

We must provide competent management,

and their actions must be just and ethical.

We are responsible to the communities in which we live and work and to the world community as well.

We must be good citizens - support good works and charities and bear our fair share of taxes.

We must encourage civic improvements and better health and education.

We must maintain in good order

the property we are privileged to use,

protecting the environment and natural resources,

Our final responsibility is to our stockholders,

Business must make a sound profit.

We must experiment with new ideas.

Research must be carried on, innovative programs developed and mistakes paid for.

New equipment must be purchased, new facilities provided and new products launched.

Reserves must be created to provide for adverse times.

When we operate according to these principles,

the stockholders should realize a fair return.

Figure 6: Johnson \& Johnson Credo. Source: www.jnj.com

To be effective, the founding story also has to possess broad appeal. For example, multinational giant Hewlett Packard (HP) was founded by Stanford University classmates

Bill Hewlett and Dave Packard in 1939. The company was founded with \$538 in start-up 
capital, banked from sources like Lucile Packard's job as secretary to the Stanford registrar. The company's first product, built in a Palo Alto garage, was an audio oscillator-an electronic test instrument used by sound engineers. One of HP's first customers was Walt Disney Studios, which purchased eight oscillators to develop and test an innovative sound system for the movie Fantasia (HP, 2010). While HP reached US\$31 billion in 2009 revenues, the company's founding story and the original garage shack is preserved and revered--and evokes the value of thrift and innovation to all 170,000 employees.

Thus, the second hypothesis is:

H2: A founding story is important to communicating and influencing organizational culture. 


\section{Symbolism and Ritual}

Symbols and rituals, which are important in creating a cohesive organizational culture, are used extensively throughout the Aeneid to invoke images such as Augustus as leader, religious piety, symbolic works of art, and the relentless march of Roman history (Richmond, 1976). An evocative and powerful symbol found in the Aeneid is the Vulcan shield given to Aeneas by his mother Venus (Gale, 1997). Quint (1989) noted that "the shield of Aeneas is an ideology of empire that informs the Aeneid.... and the advantage of ideology is its capacity to simplify, to make hard and fast distinctions and draw up sides...[and] to project a foreign "otherness" upon the vanquished enemies of Augustus and of a Rome identified exclusively with her new master" (pp. 1-3).

At the request of Venus, the Cyclopes forge the armor on the island of Vulcano while Aeneas forges his alliance with Evander in Latium. This alliance in Book VIII is far more than military expediency, however, as Evander himself is a symbol of the "good king”. He lives stoically and simply, he is pius in his recounting of how Saturn (Cronos) established local law and order and the name of Latium, and nobly and unselfishly turns his beloved son Pallas over to Aeneas. With this deeper understanding, Aeneas undertook an "enlargement of vision in Elysium and a more acute perception of his personal responsibility gained [and] does come to some realization of the significance of this succession of trials and the role allotted to him...[and] stresses the burden which is also a reward" (McGushin, 1964, p. 237).

Modeled after the Shield of Achilles in the Iliad and alluding to the Shield of Heracles by Pseudo-Hesiod (Hardie, 1985; Faber, 2000), the shield of Aeneas provides great symbolism and purpose by depicting a lengthy ecphrasis of the entire history of Rome from its founding by Romulus through to the future Battle of Actium where Augustus defeated Marc Antony's "unholy alliance" with Cleopatra and her Egyptian forces: 
Vivid in the center were the bronze-beaked Ships and the fight at the sea off Actium... Augustus Caesar leading into battle Italians, with both senators and people, Household gods and great gods: there he stood High on the stern, and from his blessed brow Twin flames gushed upward, while his crest revealed His father's star...

All these images on Vulcan's shield... Upon his shoulder all the destined acts

And fame of his descendants (Book VIII, 912-921; 987; 992-993)

The battle on the shield symbolises the values of Augustan leadership, set against the chaos of Antony and Cleopatra's forces, which "successfully vindicates his claim to be a worldruler" (Hardie, 1985, p. 31). We see the unity of Italians and Romans, households and state all under one man, a vision of order, of male virtue and steady leadership.

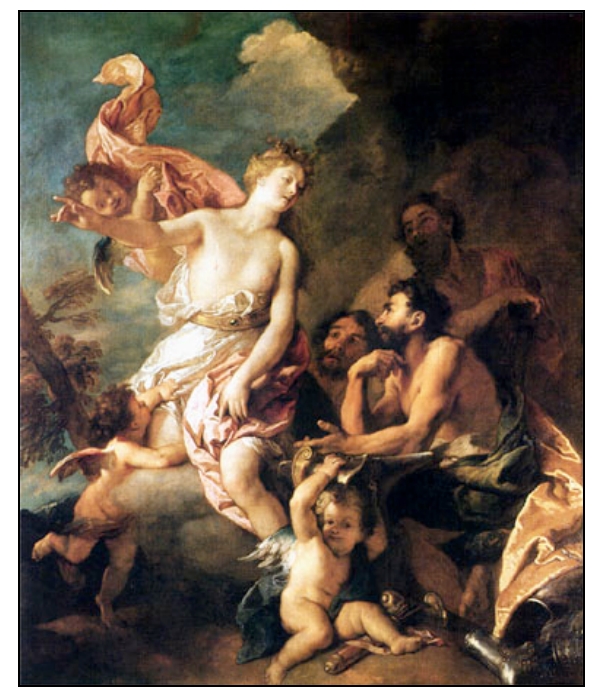

Figure 7: Venus Requesting Vulcan to Make Arms for Aeneas (c. 1690 - 1700) by Charles de La Fosse

With his armor he emerges unassailable: “...from his quarters Lord Aeneas came-The father of the Roman race_-aglow with starry shield and armor forged by heaven" (Book XII, 224-226). That is, when “Aeneas lifts his shield, he takes upon himself the responsibility for the glory and destiny of his descendants" (Eichholz, 1968, p. 105). 
All these images on Vulcan's shield,

His mother's gift, were wonders to Aeneas

Knowing nothing of the events themselves,

He felt joy in their pictures, taking up

Upon his shoulder all the destined acts

And fame of his descendants (Book VIII, 987-992)

Another effective use of symbolism in the Aeneid are the Gates of War which were well known to Virgil's contemporary Roman audience. The Gates of War were associated with the double doors at the Temple of Janus. "The temple always stands open in time of war, but is closed when peace has come. The latter was a difficult matter, and it rarely happened, since the realm was always engaged in some war, as its increasing size brought it into collision with the barbarous nations which encompassed it round about. But in the time of Augustus it was closed" (Perrin, 1914, p. 20). In Book VII, Turnus, falling to his irredeemable passion, demanded that King Latinus declare war with Aeneas, who did so reluctantly but also in shrunken cowardness:

\section{...Latinus was enjoined}

To declare war on the people of Aeneas

By setting wide the grim gates. But he would not,

Would not touch them, only turned away

From the repellent work, and shut himself

In the interior darkness.

Heaven's queen

Athis dropped from the sky. She gave a push

To stubborn-yielding doors, then burst the iron-bound

Gates of war apart on turning hinges (Book VII, 846-855)

Likewise, the shutting of the Gates of War is a metaphor for peace and prosperity, ushered in by the great deeds of the House of Iulus (which is subsequently transformed into Julius) to quell civil war-thus justifying and linking Julius Caesar's unification of Rome:

...the Gates of War

Will then be shut: inside, unholy Furor,

Squatting on cruel weapons, hands enchained

Behind him by a hundred links of bronze,

Will grind his teeth and howl with blooded mouth (Book I, 394-398). 
Augustus was proud of his role in bringing peace to the Roman world. He even boasted of his closing the gates on three separate occasions (Augustus, Res Gestae, 13) stating that in all of Roman history this had only happened twice before. This symbolism is embodied in Aeneas as he rises from the underworld in Book VI looking forward to a pantheon of future great Romans culminating in Caesar and Augustus, self-fulfilling the cyclical relationship between the past and the future, the present and the past.

In practical terms, Augustus reorganized and revivified many symbolic institutions - and made membership in them a source of social and political prestige. For example, the two languishing priesthoods of the Fratres Arvales (Brethren of the Fields) and Sodales Titii (Associates of the Titus Tatius) were revived. Augustus also built the temple of Apollo, as well as rebuilt eighty-two other temples. The revision of the venerable Libri Sibyllini (Sibylline books), influential in determining Roman policy, were symbolically transferred to the temple of Apollo. Augustus also consolidated his moral authority by becoming the Pontifex Maximus or high priest of the Collegium Pontificum (Ancient Roman College of Pontiffs), which effectively integrated the highest religious office into the imperium (Korfmacher, 1956). Augustus not only increased his auctoritas with the revival of religious institutions, but also used these offices to further blur the boundaries between private ritual and public life to useful political effect. For example, Augustus revived the Fratres Arvales and used the elite brotherhood to strengthen alliances with Roman elite, reach out to former opponents, and lay the long period of civil wars to rest (Galinsky, 1996).

In modern leadership terms, symbols and rituals can have resonant effects on organizational and cultural development. Symbolic messages are used by individuals to understand their environment and create a social reality (Blumer, 1962; 1969; Faules \& 
Alexander, 1978; Mills, 2002). For example, company logos can communicate across languages and cultures to prospective customers and employees (Aaker, 1994). The CocaCola or Fedex brand lettering, for example, maintains their identical physical appearance worldwide and provides ubiquitous messaging to customers.

Symbols can also be important to employees and shareholders (Dutton \& Dukerich, 1991). Schmitt \& Simonson (1997) describe the splitting off of Lucent Technologies from AT\&T. The new company sought to establish an identity for itself and for the public through a new name, logo, and advertising campaign. All employees received a brochure describing the new name- - Lucent — and the suggestion that the name represented light and clarity. Along with the new name was a picture of the bright red hand-drawn "Innovation Ring" logo, which was said to symbolize knowledge and "the creativity of our people" (Schmitt \& Simonson, 1997, p. 28). Discussions of the new name, the new logo, and other organizational symbols provided a way for organizational members to understand the identities and values that come along with a major organizational change.

Thus, the third hypothesis is:

H3: Symbols and/or rituals are important to creating a cohesive organizational culture. 


\section{$\underline{\text { Values-based leadership }}$}

Values-based leadership is defined as the moral foundation underlying stewardship decisions and actions of leaders. As Aeneas struggles with the tension between private happiness and public service, his values are forged. That is, through his challenges Aeneas experiences a catabasis or turning point that "transforms Aeneas from a more or less Homeric hero to a Stoic ideal. After his descent to Hades, Aeneas has complete knowledge of the future; and true virtue, according to the Stoic view, is the result of knowledge" (Fuhrer, 1989, pp. 63-64). As Cicero (54 BCE) presaged, "virtue herself, by her own charms, should lead you on to true glory" (trans. Keyes, 1928, p. 279). In this study, the Aeneid was coded into the following eight values (or virtus): integrity, good judgment, leadership by example, decision-making, trust, justice/fairness, humility, and sense of urgency.

As Aeneas realizes the responsibility of his mission and values, he is continuously elevated throughout the epic as if in an incessantly building crescendo. As Miller (1928) summarized: “A great cause needs a great leader. And while Aeneas is always to Virgil the perfect hero and shines as the patiently all-enduring one, the matchless warrior, the merciful conqueror, the wise and fatherly ruler, his greatest role is that in which the poet first introduces him: the man of faith, who believes implicitly in his destiny, who constantly seeks and expects divine guidance and fulfillment" (p. 30). The tension between values provides a dynamic insight into the exercise of leadership and human nature as "the Aeneid is not woodenly moralistic, and we have been led to be understanding towards the hero, with his great emotional pressures and changing duties, but his action at the end cannot escape moral scrutiny" (Burnell, 1987, p. 198). As MacKay (1963) noted, the Aeneid "depicts the triumph of the depersonalized will, the establishment of human values by inhuman means" (p. 164). 
Values can be personal, moral, social and organisational—and are dynamic and contextual. In reflecting on the long arc of the Roman imperium, “...the outstanding fact about Rome is her unwavering adherence to the idea of a controlled life, subject not to this or that individual, but to a system embodying the principles of justice and fair dealing" (Hamilton, 1932, p. 193). As Cicero (54 BCE) noted about the inherent tension in reflecting on values: "Everyone has the obligation to ponder well his own specific traits of character. He must also regulate them adequately and not wonder whether someone else's traits might suit him better. The more definitely his own a man's character is, the better it fits him" (p. 111). In other words, a value is also a form of social cognition that guides an individual's adaptation to the surrounding environment or as Gardner (1980) noted, "the play of conflicting interests in a framework of shared purposes is the drama of a free society" (p. 15). O’Toole (1993) has characterized these tensions or trade-offs in a free society as moral choice between four poles: liberty, equality, community and efficiency (e.g., economic freedom versus social equity). The dynamic and contextual character of values reveal its tension as:

[Leaders] have seen that in stressing one value (individual competition, for example), they sacrifice other equally necessary values (such as cooperation)....the art of leadership requires the simultaneous pursuit of several values-values that, in the simplicity this side complexity, appear incompatible...[leaders] must abandon their constant search for the immediately practical and, paradoxically, seek to understand the underlying ideas and values that have shaped the world they work in (p. 7). 


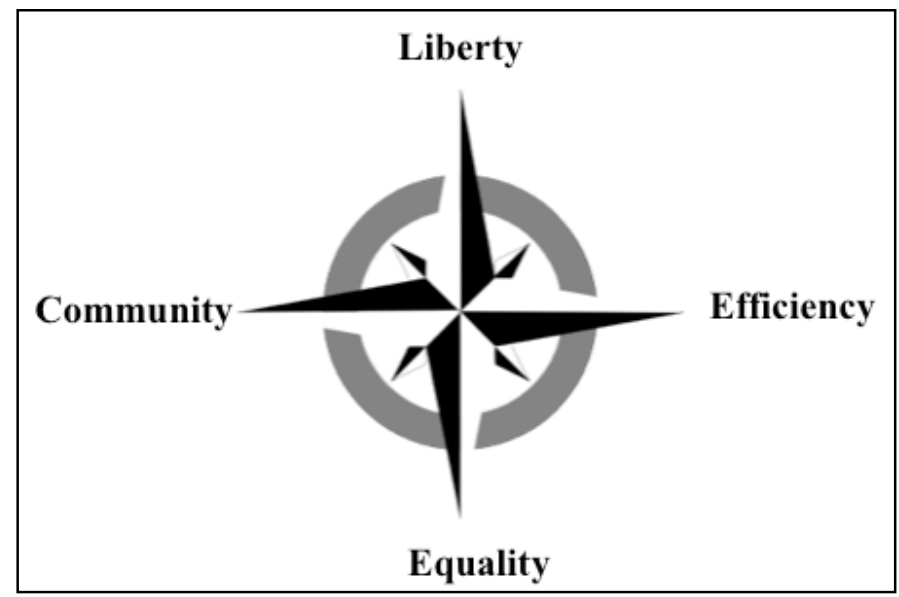

Figure 8: Value trade-offs in a free society as moral choice between four poles: liberty, equality, community and efficiency. Source: O'Toole (1993)

In other words, transformational leadership is prescriptive about the nature of morally good leaders who "have to operate at higher need and value levels than those of followers. A leader's role is to exploit tension and conflict within people's value systems and play the role of raising people's consciousness...transforming leadership is concerned with end values, such as liberty, justice and equality" (Ciulla, 1998, p. 15). In this context, Rokeach (1973) classifies values according to terminal and instrumental values. Terminal values are desirable end-states and outcomes which can be divided into social and personal values. Examples of such values are freedom, equality, morality, politeness and courtesy. Instrumental values, on the other hand, are modes of behaviour necessary to achieve desirable outcomes and are more intrinsic as they affect the processes which an individual will undertake or avoid.

In leadership terms, values also provide rationale for conceptions of desirable objects and objectives — and influence the degree to which a leader's actions are viewed as legitimate, acceptable and effective. As McGregor Burns (1995) defined "leadership as leaders inducing followers to act for certain goals that represent the values and the motivations - the wants and needs, the aspirations and expectations - of both leaders and followers" (p. 100). This 
rationale provides a 'binding effect' to draw certain people who have similar aspirations and goals to cooperate together, and form the basis of an organisation (Buchko, 2006). Without similar or corresponding value sets, starting or managing an organisation will be difficult as transformational leadership is linked to virtue and moral character (Bass \& Steidlmeier, 1999). As Gardner (1995) noted, "shared values are the bedrock on which leaders build the edifice of group achievement. No examination of leadership would be complete without attention to the decay and possible regeneration of the value framework" (p. 5).

Values operate and exist at multiple levels-societal, organisational and personal- to influence organisational behaviour and performance (Grojean, Resick, Dickson \& Smith, 2004). Organisational or corporate values are slightly different since they are usually specific, formal and publicly-stated; and employees are expected to adhere or believe. Such values often connect and establish corporate visions, strategies and shape the organisation's public relations atmosphere. Organisational values also prompt behaviours that facilitate efficient interactions between individuals and this allows greater organisation and cohesion. In a global study of long-term determinants of premier for-profit and non-profit organizations, Collins and Porras (1994) found that core values which were deeply believed and adhered to are critical to extraordinary performance:

Core values are the organization's essential and enduring tenets-a small set of general guiding principles; not to be confused with specific cultural or operating practices; not to be compromised for financial gain or short-term expediency... in a visionary company, the core values need no rational or external justification. Nor do they sway with the trends or fads of the day. Nor even do they shift in response to changing market condition (pp. 73-75).

As such, the values of leaders and employees can become embedded into the social fabric of the organisation and shape the culture and establishes organisational assumptions. Schein (1992) identifies and segments this occurrence into primary and secondary mechanisms on 
how a leader's values can become embedded in the organisation's culture. Thus, understanding values is integral to understanding leadership as it explains focus and value of people's actions and efforts (Fernandez \& Hogan, 2002). Once employees understand the value and focus of their efforts, company leadership is able to define the organisation's greater mission and milestones.

Further, organisational structures appear to have a role in determining value sets as control is administered differently between hierarchical and flat structures (Pruzan, 1998; Anderson, 1993). With lesser bureaucracy in flat organisational structures, the emphasis is on self-autonomy and on employees self-administering and becoming independent. By contrast, in more hierarchical organisational structures, middle-management and bureaucracy dictate and 'guide' appropriate behaviour of employees. In other words, cohesive values can be an efficient and effective means of governance in both the far flung Roman empire as well as the multinational firm. As such, values provide a sustainable foundation for profitability beyond profits by providing purpose for employees and stakeholders. As Richard Clark, CEO, of multinational pharmaceutical firm Merck stated unequivocally: "we pride ourselves in our scientific ability and integrity. Our ethical standards are the foundation of our Company" (2005, p. 220). Another example is multinational biotechnology company Biogen-Idec's vision, mission, and core values stated as: 


\section{biogen idec}

Transforming Discovery into Care

Vision: With passion, purpose and partnerships, we transform scientific discoveries into advances in human healthcare.

Mission: We create new standards of care in neurology, oncology and immunology through our pioneering research, our global development, manufacturing and commercial capabilities.

\section{Core Values}

- Courageous Innovation: We apply our knowledge, talent and resources to yield new insights and bold ideas. We confront challenge and uncertainty with zeal, tenacity and vision and seize opportunities to excel.

- Quality, Integrity, Honesty: Our products are of the highest quality. Our personal and corporate actions are rooted in mutual trust and responsibility. We are truthful, respectful and objective in conducting business and in building relationships.

- Team as a Source of Strength: Our company is strong because our employees are diverse, skillful and collaborative. We pursue our fullest potential as individual contributors, team members and team leaders.

- Commitment to Those We Serve: We measure our success by how well we enable people to achieve and to thrive. Patients, caregivers, shareholders and colleagues deserve our best.

- Growth, Transformation and Renewal: Consistent with our core values, we as individuals and as a corporation are dedicated to creative and constructive growth, transformation and renewal as a source of inspiration and vitality.

Figure 9: Biogen-Idec Vision, Mission and Core Values. Source: www.biogenidec.com

Another example which extends organizational values into the broader stakeholder community is multinational food giant Nestlé who developed an initiative called Creating Shared Value (CSV) to address pressing global needs in three key areas: nutrition, water and rural development (Nestle, 2010).

For a business to be successful in the long term, it must create value not only for its shareholders but also for society. At Nestlé we recognize that our success means creating value for everyone we touch - from the farmers who supply our products, to our employees, to our consumers and the communities where we operate. We call this commitment Those areas are core to our company's business strategy and essential to creating a better and healthier world in the 21st century...to deliver long-term value to its 
shareholders, its approach to corporate social responsibility must go beyond a commitment to complying with laws, sustaining the environment and conserving energy.

In the following section, each of the eight identified leadership values coded from the Aeneid are reviewed in the context of the epic. The eight values, in order of importance, were coded as: integrity, good judgment, leadership by example, decision-making, trust, justice/fairness, humility, and sense of urgency. In addition, each value or virtue is reviewed in its contemporary Roman context, as well as juxtaposed to a modern perspective to establish working hypotheses, which may then be tested to explore the relevance of the Aeneid to the demands of modern leadership. 


\section{$\underline{\text { Integrity }}$}

Integrity may be defined as the steadfast adherence to a strict moral or ethical code. Whether through positive reinforcement or negative punishment, the importance of integrity in the form of pietas towards the anthropomorphic gods is a central feature of the Aeneid (Hahn, 1931; Coleman, 1982). We know that contemporary Romans valued this kind of integrity. In the Metamorphoses, Ovid (18 AD) noted that: "No man can purchase his virtue too dear, for it is the only thing whose value must ever increase with the price it has cost us. Our integrity is never worth so much as when we have parted with our all to keep it." (trans. Miller, 1916, p. 117). The importance of public life and private morality, as well as the blurred boundaries, was a central feature of Augustan rule. The real world of Virgilian politics meshed with the idealised one of his poem. McGushun (1964) puts this well when he states that: "Augustus is the Aeneas of the Rome which has emerged from the turmoil of civil strife and which must return to the simple virtues of pietas and endurance if it is to realize the fulfillment of its destiny" (p. 252).

For offerings, veil your head in a red robe Against intrusions on your holy fires, Omen-unsettling sights amid your prayers. You and your company retain this ritual

Veiling in the future, let your progeny

Hold to religious purity thereby (Book III, 546-553)

Even when Aeneas's resolve was shaken by Pallas' death and the battle called for action, he ensured that all obligations were met: “...duty pressed him to give time, for burial to the dead, he first in early light discharged his ritual vows as victors to the gods" (Book XI, 3-6).

Those around Aeneas display the alternatives to his own character and as such to the promised future. A good alternative example shows the behaviour of Dido as she, through her passion for Aeneas, allows her leadership to cease, her city stops growing, buildings lie 
unfinished and ultimately she loses all in suicide. Virgil's readers would know only too well that her city's destiny lay on the same path as its female founder - the Romans destroyed Phoenician Carthage in 146 BCE. Aeneas' stoicism provides steady reassurance of his actions:

Detest me, my own Tyrians are hostile;

Because of you, I lost my integrity

And that admired name by which alone

I made my way once towards the stars...

The man by Jove's command held fast his eyes

And fought down the emotion in his heart (Book IV, 439-442; 456-457)

A central role of Dido, variously translated by Purcell, Dryden, Berlioz and others, is to emphasize the pietas of Aeneas (McLeish, 1972) and reinforce the moral gravity of virtuous behaviour characterized in the reforms of Augustus (Korfmacher, 1956). As Cicero (54 BCE) opined: "Law ought to be a reformer of vice and an incentive to virtue" (trans. Keyes, 1928, p. 363).

By comparison, Augustus in the Res Gestae prominently emphasized his pietas by way of adherence to the letter and spirit of collective rule. Of note, he underlines that those who adhere to these traditional values should be admired and rewarded (Earl, 1967). For example, he eschewed the offer of absolute power and instead aligned himself with the people and traditional republican values and "in listing these honours he more than once stresses that they were bestowed by the people as well as the senate, and emphasizes that he was unwilling to accept untraditional, i.e. unrepublican, honours and powers" (Brunt \& Moore, 1967, p. 5). As Augustus (Res Gestae, 34) wrote:

In my sixth and seventh consulships, when I had extinguished the flames of civil war, after receiving by universal consent the absolute control of affairs, I transferred the republic from my own control to the will of the senate and the Roman people. For this service on my part I was given the title of Augustus by decree of the senate, and the doorposts of my house were covered with laurels by public act, and a civic crown was fixed above my door, and a golden shield was placed in the Curia Julia whose inscription testified that 
the senate and the Roman people gave me this in recognition of my valour, my clemency, my justice, and my piety. After that time I took precedence of all in rank, but of power I possessed no more than those who were my colleagues in any magistracy (trans. Cooley, 2009, p. 98).

Integrity is likewise central to modern leadership studies, which may be viewed as "commitment in action to a morally justifiable set of principles" (Becker, 1998, pp. 157-158) and is a prerequisite to transformational leadership. Parry \& Proctor-Thompson (2002) found, in a study of 1,354 managers, a positive correlation between perceived integrity and transformational leadership behaviours or the ability to motivate, encourage and induce people to be aware of how they feel and take purposeful action to achieve desirable end-states (MacGregor Burns, 1978) beyond personal interests and limitations, and collectively for the organisation (Grojean, Resick, Dickson \& Smith, 2004). Similarly, another study of leaders across 62 countries found that integrity-based leadership — defined as just, honest and trustworthy — was a superordinate, universal value (House, Hanges, Javidan, Dorfman, \& Gupta, 2004). That is, beyond a focus on individual behaviour and legal compliance, leaders can have a significant effect on organizational performance. As Paine (1994) posits, “an integrity-based approach to ethics management combines a concern for the law with an emphasis on managerial responsibility for ethical behaviour... and to instill a sense of shared accountability among employees" (p. 106).

An example of integrity in leadership involves the actions of Jim Hackett, CEO of Steelcase, an office furniture company. When it was discovered that the company's wall panels potentially did not meet fire standards, several insiders were reluctant to make changes. The fact that fire codes were so variable and that there had never been any customer complaints about the panels were just some of the rationale presented to Hackett. Hackett, however, endeavoured to maintain Steelcase's reputation for unyielding integrity and 
therefore implemented the needed changes. The decision cost $\$ 40$ million and resulted in Hackett and his team losing their annual performance bonuses. Years later, the United States Department of Defense became one of Steelcase's customers. The updated panels were installed in the perimeter walls of the Pentagon before the terrorist attacks of September 11, 2001, an event that ultimately destroyed a section of the walls. Upon a post-attack Pentagon review of the building materials, Hackett recounts the agency's findings: "If the new Steelcase material was not there, the fire would have spread in a far more disastrous outcome" (Tichy \& Bennis, 2010).

Thus, the following hypothesis is posited:

$\mathbf{H 4}_{1}$ Integrity, defined as the steadfast adherence to a strict moral or ethical code, is an important leadership value. 


\section{Good Judgment}

Good judgment, tempered by flexibility and situational awareness, may significantly influence performance. The development and transformation of Aeneas is a striking example of a leader being forged by tests of character through a series of judgment calls. Unlike many literary references for Virgil, particularly Homeric characters who are typically monochromatic, Aeneas "is not the same sort of individual in the first part of the Aeneid as he is in the books that deal with him after his arrival in Italy" (Howe, 1930, p. 183). What makes the character of Aeneas so compelling and timeless is his struggle to be moral despite missteps, challenges and temptations. For example, in Aeneas' passion for Dido "his sin lies not in his love, but in the abandonment of his god-given mission" (p. 188).

Another crucial aspect of leadership judgment is to know when to forge alliances to manage risk and when to be self-reliant. In other words, the effect of good judgment is not simply focusing on priorities, but also eliminating non-priorities. After establishing a foothold on the Tiber, for example, Aeneas and his Trojan followers attempt to forge an alliance with the nearest competent local authority, King Latinus of Laurentum (Alexander, 1945). As Cicero in De Legibus (On the Laws) in 52 BCE noted on good judgment, "...choose the good and reject the opposite — virtue which is called prudence because it foresees - then what greater degree of happiness can be described or imagined" (trans. Keyes, 1928, p. 61).

By comparison in the political realm of the Res Gestae, Augustus exercises good judgment not to overreach his power and learns from the enmity which his predecessor Julius Caesar injured after becoming dictator perpetuus (dictator in perpetuity). For example, Augustus emphasized that while the people and senate bestowed many accolades and titles 
upon him, he was always unwilling to accept honours and powers which were not in the republican tradition:

The dictatorship offered me by the people and the Roman Senate, in my absence and later when present, in the consulship of Marcus Marcellus and Lucius Arruntius I did not accept. I did not decline at a time of the greatest scarcity of grain the charge of the grainsupply, which I so administered that, within a few days, I freed the entire people, at my own expense, from the fear and danger in which they were. The consulship, either yearly or for life, then offered me I did not accept (trans. Cooley, 2009, p. 62).

In modern leadership, organizational performance depends on the quality of judgments made by key decision makers. Tichy \& Bennis (2010) assert that “good judgment isn't about luck, common sense, or gut instinct - it is more like a drama with plot lines, characters, and unforeseen twists and turns" (p. 11). Correctly addressing these twists and turns involves careful attention to three phases of action-taking: preparation, making the call, and execution. First, preparation involves a vigilant diagnosis of oneself and one's surroundings, as well as an awareness of how action or inaction will affect stakeholders. The factor that best determines how well one makes decisions is introspection, which points to the heightened significance of the preparation phase. Next, exercising judgment focuses on clear communication and explanation of the action taken, and finally execution centers on offering guidance and support in congruence with the decision, while also allowing for adjustments to be made (Moyer, 2009; Tichy \& Bennis, 2010).

Because leaders find themselves confronted with a variety of circumstances, flexibility, especially in the execution stage, becomes paramount to good judgment. A study by Goleman (2000) reported that leaders who are able to adapt their styles and approaches according to the situation at hand are superior in terms of overall effectiveness. When flexibility is combined with rational thought, leaders are able to reach sound conclusions. An example of this insight is illustrated through Proctor \& Gamble CEO A.G. Lafley's appointment of Deb 
Henretta to lead the baby care segment of operations. This particular segment was struggling, and Lafley determined that it was because manufacturing executives were in charge and therefore had no connection with the consumer. Lafley knew that a change in leadership was necessary and he made the tough call of bringing in Henretta to turn the division around. The reaction to Henretta's appointment was "almost a revolt" and Lafley had to quickly adjust his approach. He realized that without support from her new colleagues, Henretta was doomed to fail. Therefore, Lafley met with his team to listen to their complaints and explain the reasoning behind his action. As a result, he soothed the opposition and Henretta was able to successfully transform the baby care division (Tichy \& Bennis, 2007). In a broader context, Larry Bossidy, CEO, Allied Signal advised:

Good executives...know when a situation calls for their immediate involvement, whether it's in redirecting resources to a product that's suddenly taking off in the market, helping to resolve a breakdown in quality, or visiting a plant to discover why its productivity has faltered. There's no excuse for not taking responsibility when you see a problem...I count on my reports to take the blame for things that go wrong and give credit for positive developments to their employees. And I expect them to have the courage to deliver bad news... While there are no hard-and-fast rules about when your involvement will have the most impact on the business (that's a judgment call), I've found that good managers generally step in under three types of circumstances: when somebody is falling behind in her commitments; when important personnel matters arise, particularly if there is conflict; and in a crisis (2007, p. 60).

Thus, the following hypothesis is posited:

H4 $4_{2}$ Good judgment--Good judgment, tempered by flexibility and situational awareness, significantly influences performance. 


\section{Leadership by Example}

Leadership by example may be defined as the collective actions, decisions and general deportment of leaders (e.g., personal sacrifice, servant leadership). After suffering great loss of men and material in their opening voyage, Aeneas' first action after landing in Libya was to climb a peak to assess their strategic situation and to benefit the welfare of his people, as well as to reassure them of their safety and secure food:

Aeneas climbed one of the peaks

For a long seaward view...

He found no ship in sight, but on the shore

Three wandering stags. Behind them whole gerds followed...

Next he routed the whole herd...

A number equal to his ships. Then back

To port he went and parceled out the game

To his ships' companies. (Book I, 256-258; 263-264)

After many setbacks and false starts, Aeneas' pietas is fully internalized after his father lays out the vision of Rome and "the crucial difference... from the earlier books is that compulsion is now inside him, which makes it all the grimmer. Duty and choice are joylessly but indissolubly one" (Wilson, 1969, p. 70). As Aeneas solemnly instructs his son after being wounded in the first battle of the book:

My son, learn courage and real endurance from me

Learn happiness from others (Book VII, 435-436)

Ultimately, however, self sacrifice to a cause larger than oneself is the most resonant act of commitment to an envisioned future. The heroic and selfless actions of Nisus and Euryalus to conduct a night sortie and daylight assault to exploit a tactical weakness, a lack of enemy discipline in drinking too much wine during ongoing battle operations and their familiarity with local terrain, made Turnus' encampment vulnerable to a guerrilla attack. Rather than seeking self aggrandizement, Euryalus selflessly puts mission first and only requests that his mother be consoled in the event of his death. The pair quietly infiltrate the enemy camp in 
what would likely be a deadly mission, which wreakes substantial terror and death among enemy officers and men.

...But we make out An opening for a sortie where the road Divides there at the gates nearest the sea...If you let us

Take advantage of this and find our way

To Aeneas and Pallanteum, you'll see us back With plunder before long, and slaughter done. No fear the path will fool us: many times, Hunting these valleys, we have come in view Of the town's outposts, and we know the river, The whole course of it (Book IX, 330-340)

The heroic efforts of Nisus and Euryalus, during which they were killed and piked on spears, wreak havoc on Turnus forces and help repel their attack, and underscore Jupiter's observation that "...the effort that each man makes will bring him luck or trouble" (Book $\mathrm{X}, 154-155)$. By their actions and "obedience Aeneas and his followers show their pietas; in the lack of such obedience their opponents shows their violentia" (Hahn, 1931, p. 665):

On his left arm holding the shield ablaze

He raised it up now. From the walls of the Trojans

Shouted to heaven. Hope reawakened wrath...In the lead

Aeneas broke through with troops from the countryside-

A first good omen for the fight to come (Book X, 363-365; 428-430)

As Cicero (52 BCE) extolled, "the soul of all men are immortal, those of good and brave men are divine" (trans. Keyes, 1928, p. 405).

From a modern leadership perspective, leadership by example plays a powerful role in enhancing the motivation and performance of followers. Gachter \& Renner (2003) found a strong correlation between leader and follower contribution, showing that the more a leader sacrifices, the higher the contributions of subsequent followers (Guth, Levati, Sutter, \& Heijden, 2007). Cuoto (1995) expands on this notion:

The transforming leader shapes, alters, and elevates the motives and values and goals of followers...There is a special power entailed in transforming leadership. Leaders armed 
with principles and rising above self-interest narrowly conceived are invested with power that may ultimately transform both leaders and followers into persons who jointly adhere to modal values and end-values (p. 103).

Several paradigms, most notably servant leadership and leadership in extremis (extreme circumstances), have been developed to classify the unique characteristics of this transforming leader. Servant leadership explains how true servant leaders transform their followers to "grow healthier, wiser, freer, more autonomous, and more likely themselves to become servants" (Sendjaya \& Sarros, 2002, p. 37). Leadership in extremis, on the other hand, focuses on the behaviours of leaders during times of intense crisis, such as life-or-death situations. Kolditz (2007) posits, "in extremis leaders place more value on taking care of their clients, followers, soldiers, and citizens than they place on their own comfort, personal safety, or wealth" (p. 17). He further notes that how one behaves during a crisis is not only a solid indicator of loyalty toward an organization, but also a clear snapshot of one's true character and resolve.

In the armed forces, selfless acts of leadership during times of peril are held in such high esteem as to earn the highest levels of praise, reward and recognition. In the United States, the Medal of Honor is reserved for one who has performed an act of "personal bravery or self sacrifice so conspicuous as to clearly distinguish the individual above his comrades and must have involved risk of life" (Department of the Army, 2002). Likewise, the Victoria Cross is awarded to members of the armed forces in the United Kingdom and other Commonwealth countries for someone who in the face of an enemy "shall have performed a signal act of valour" (National Archives, 2010).

In the business sector, Gerald Grinstein, former CEO of Delta Airlines, has embodied these principles through selfless dedication to his company. In 2007 , he refused over $\$ 10$ million in compensation promised to him after guiding the airline through bankruptcy. 
Instead, he contributed the money to Delta scholarships and hardship assistance for employees and their families. This action "almost singlehandedly defused employee resentment and regained employee trust and confidence in Delta management" (Citrin, 2009).

In other words, leadership by example creates a multiplier effect throughout the organization which significantly strengthens culture, cohesion, and enhances efficiency. As one CEO noted: "I'm not calling for grand gestures. What I am talking about is the quiet daily work of leading by example and doing things the right way. Instead of minimal compliance that violates the spirit of the rules and throws real ethics out the window, let's make it clear that values aren't based on convenience, nor are they relative" (Keating, 2010, p. 148).

Thus, the following hypothesis is posited:

$\mathrm{H4}_{3}$ Leadership by Example is the collective actions, decisions and general deportment of leaders (e.g., personal sacrifice). 


\section{Decision Making}

Decision making is defined as the steadfast adherence to and support of directives that follow the chain of command, unless requested actions are immoral, illegal or unethical. The exercise of effective decision making in uncertainty faces Aeneas throughout his journey. We see the hero transform from a man beset with doubts (as from the start he wishes he too had died at Troy in Book I, 94-101), making indecisive or poor decisions (as for example at Carthage) or even acting not as a leader but a follower under the gaze and auspices of his aged father (under whom a litany of poor decisions are made in Book III). After great sacrifice and heroism, for example, Aeneas could have dictated peace on his own terms, which would have been more costly to enforce and potentially threaten sustainable administration after successful prosecution of military action. Instead, as Drances recognized "in war there is no salvation" (Book XI, 493); and finally in Book XII Aeneas declares:

If on the hand the day is ours,

Conferred by divine victory, as I think

...For myself I ask no kingdom.

Let both nations, both unconquered, both

Subject to equal laws, commit themselves

To an eternal union. I shall give

Rituals and gods to both (Book XII, 252-62).

In modern leadership, the capacity to make and commit to a decision with imperfect information becomes paramount, particularly when faced with time and resource constraints. Leaders must not only assess the consequences of their decisions for all stakeholders involved, but they must also strive to avoid internal biases that affect rational decision making (Messick \& Bazerman, 1996). Ultimately, executives must confront the reality that the decisions they make will leave some stakeholders unsatisfied. As General Colin Powell explains: 
I learned that being in charge means making decisions, no matter how unpleasant. If it's broke, fix it. When you do, you win the gratitude of the people who have been suffering under the bad situation... you cannot let the mission suffer, or make the majority pay to spare the feelings of an individual. (Powell, 1996, p. 35).

Two pitfalls that commonly affect decision makers are "decision task neglect" and "analysis paralysis". "Decision task neglect" refers to the tendency to avoid making a decision because the process of decision making is deemed too complex to undertake. On the other hand, "analysis paralysis" refers to a habit of continuously gathering more and more information because the consequences of making a bad decision are high and the decision maker does not want to confront the risk (Zell, Glassman, \& Duran, 2007).

One executive who has successfully avoided these pitfalls is David Perlmutter, executive vice president at Intel. During his thirty year tenure at Intel, Perlmutter saw the company grow into the $\$ 132$ billion corporation that it is today. Perlmutter currently manages Intel's Architecture Group, which brings in ninety percent of the company's profits, and he is responsible for 22,000 of Intel's 83,000 employees. Each workday presents a myriad of decisions to make, but Perlmutter finds himself comfortable in the presence of risk and uncertainty. He imparts this advice:

One of the problems is that executives wait for more parameters to lower the risk, but waiting only increases risk. I make a decision and go with it. It doesn't mean I don't check my decisions repeatedly. Sometimes there are changes. I try not to be foolish, although it happens, too (Grimland, 2010).

As Larry Bossidy, CEO, of multinational Allied Signal advised: "Decisiveness isn’t useful if it isn't timely. People should expect me to make decisions as soon as I have the information I need, and not to be careless or impetuous but to give clear, unambiguous answers... The problem is, people are often reluctant to get the boss involved for fear that asking for help will be perceived as a sign of weakness. They end up asking just when they 
think they're going to lose the deal. I consider asking for help a sign not of weakness but of self-confidence." (2007, p. 64).

Thus, the following hypothesis is posited:

$\mathbf{H 4}_{4}$ Decision Making defined as the steadfast adherence and support of directives that follow the chain of command, unless requested actions are immoral, illegal or unethical 


\section{$\underline{\text { Trust }}$}

Trust is defined as a relationship of reliance between leaders and followers. The presence of trust allows for the full commitment of followers, enables organizational cohesion, and enhances performance. In this case, Aeneas builds trust by showing mercy to those conquered (Book XII, 252-261), as well as his alliance with the Arcadians:

Trust us as we trust you. We have the stamina

For warfare, and have the spirit for it.

In difficulties our men have proved themselves (Book VIII, 201-203)

This trust is well demonstrated in the death of Pallas. Aeneas feels he has betrayed the ultimate faith his father had in him (see Book XI, 42-58), but of course the fact that Evander entrusted his son to Aeneas in war is a testament to that trust. Throughout the poem trust develops and grows. On the part of Aeneas, he increasingly trusts his own destiny and that established by the gods for his people's future. Those who follow him to Italy never waiver, though those who do not wish to continue he leaves behind in Sicily (Book V). Fides appears in every book of the Aeneid. Several of Aeneas' followers (e.g. Orontes in Book I, 102, and Achates in Book XII, 383) are described as faithful and which appears often in Book IVonly to later illustrate broken faith, though vain it was (Book IV, 12) that Dido appears to feel at Aeneas' departure (her own oath to Sychaeus in Book IV, 522) and his own justification of his own duty for leaving (see Book IV, 584).

In modern leadership, trust is playing an increasingly vital role in organisations. Mayer (1995) attributed this trend to: (1) the emergence of a largely diversified workforce which prevents workers from relying on interpersonal similarities to form working relationships; and (2) the implementation of self-directed work teams which leads to an increase in worker interaction and a decrease in control mechanisms. Because of the level of follower vulnerability (e.g., risk to one's reputation, prospect of promotion) and uncertainty (e.g., 
unfamiliarity with the leader's motivations), the relationship between leader and follower presents an element of risk (Burke, Sims, Lazzara, \& Salas, 2007). Mayer cites ability, benevolence, and integrity as three main factors of perceived trustworthiness. If all three components are present, a higher incidence of risk-taking in the relationship exists. According to Dirks and Ferrin (2002), elevated levels of trust in an organization's leadership enhances (in order of magnitude) work attitudes, citizenship behaviours, and job performance, which is ultimately linked to worker effectiveness and productivity.

Conversely, a lack of trust can prove costly and detrimental to productivity for an organization. The prevalence of corporate scandals over the past decade such as Enron, WorldCom, and AIG has diminished trust in the leadership of large corporations. In 2009, the Edelman Trust Barometer reported that less than $50 \%$ of people surveyed in the United States, Germany, France, United Kingdom, and Italy expressed trust in businesses to do what is right. One remedy to restore trust is to pass regulations that put in place additional controls to prevent fraud and corruption. These regulations have created significant costs for organizations that must now bear the burden of meeting compliance standards. As Jeff Kindler, CEO of multinational pharmaceutical Pfizer ominously noted:

Across society, people have come to believe that the rules meant to bring order to society instead are manipulated to benefit the rule-makers...People have had enough, and the backlash is real. It's fueling demands for more restrictions on business and governments. People say, "Banks should risk less, and pay their executives less. Oil companies should drill less, and burn less. Drug companies should charge less, but not do less R\&D." Sometimes, this criticism is warranted. Sometimes, it's not. But when the majority of people don't trust you, they'll find a way to force you to change (2010, p. 59).

On the other hand, an abundance of trust can also serve to decrease an organisation's internal and external operating costs by increasing the speed of transactions. For example, in May 2003 Warren Buffet's Berkshire Hathaway purchased Wal-Mart's McLane distribution unit for approximately $\$ 1.5$ billion. The deal, which would typically take months to negotiate 
and cost millions of dollars in due diligence, was made in a two hour meeting and finalized in less than one month. The level of trust was so great between the companies that Buffet recounts: "We did no due diligence. We knew everything would be exactly as Wal-Mart said it would be-and it was" (Covey 2007).

Thus, the following hypothesis is posited:

$\mathbf{H 4}_{5}$ Trust is defined as a relationship of reliance between leaders and followers 


\section{Justice/Fairness}

Justice and fairness defined as the perceived level of impartiality and equal treatment is a prerequisite for ensuring maximum effort and sacrifice from followers. The Aeneid illustrates that committing a nation's treasure and blood takes much more than issuing orders, as King Evander hailed the justification of fighting to restore peace:

Saturn came here in flight from Jove in arms, An exile from a kingdom lost; he brought These unschooled men together from the hills

Where they were scattered, gave them laws, and chose

The name Latium...

In his reign were the golden centuries

Men tell of still, so peacefully he ruled, Till gradually a meaner, tarnished age

Came on with fever of war and lust of gain (Book VIII, 424-428; 430-433)

As well as justification for civil war and the overthrow of a 'bad' king:

...No long way

From here men live in the city of Agylla,

Built of ancient stone.... and for years

The city flourished, till an arrogant king, Mezentius, ruled it barbarously by force...

He made them

Suffer great corruption, oozing gore and slime

In that wretched embrace, and a slow death.

But at long last the townsmen, sickening

Of his unholy ways, took arms and laid

Siege to the madman and his house (Book VIII, 642-648; 655-659)

On a personal level, Aeneas defended the honor of his fallen comrade Pallas who had been mocked by Turnus. In Roman times, it was considered abhorrent to wear the armor of enemies and justice ultimately demands that Turnus' violentia must be responsible for his own death. In this case, Aeneas calls for single combat with Turnus which he readily accepts. After intense fighting, Aeneas finally spears him in his thigh. Turnus concedes defeat and asks that his body be given a proper burial, then asks for his life to be spared. However, 
Aeneas sees Pallas' sword belt around Turnus and, in a final rage, exacts his vengeance slaying Turnus with his sword:

\author{
...the strap \\ Young Pallas wore when Turnus wounded him \\ And left him dead upon the field; now Turnus \\ Bore that enemy token on his shoulder- \\ Enemy still. For when the sight came home to him, \\ Aeneas raged at the relic of his anguish \\ Worn by this man as a trophy. Blazing up \\ ...he called out: \\ "...This wound will come \\ From Pallas: Pallas makes this offering \\ And from your criminal blood exacts his due (Book XII, 1285-1295).
}

As Cicero (54 BCE) evoked the humble virtues of Romulus, founder of Rome, who "waged many wars against his neighbors with the greatest good fortune, and, though he brought none of the booty to his own home, he never ceased enriching his own people. He also gave complete obedience to the auspices, a custom which we still observe to the great security of the State (trans. Keyes, 1928, p. 125). By comparison, Augustus in the Res Gestae (13) underscores the primary focus of imperial war is peace and security; and that magnanimity and mercy should be extended to conquered peoples whenever possible:

Wars, both civil and foreign, I undertook throughout the world, on sea and land, and when victorious I spared all citizens who sued for pardon. The foreign nations which could with safety be pardoned I preferred to save rather than to destroy (trans. Cooley, 2009, p. 60).

From a modern leadership perspective, justice has been linked to work commitment, job satisfaction, and organisational citizenship behaviours (Moorman, Niehoff, \& Organ, 1993). There are two forms of justice, distributive and procedural, that have garnered the attention of organizational theorists. Distributive justice refers to the fairness of an outcome, while procedural justice focuses on the processes used to make decisions. Distributive justice relates to equity theory which is the tendency of people to alter their behaviours or attitudes 
to restore a sense of fairness if they are unsatisfied with an outcome (Williams, 1999). Procedural justice, on the other hand, is based upon two main principles that have been found to correlate with increased perceptions of fairness: the amount of "say" a person has in a decision and the extent to which the decision maker justifies and explains the decision (Greenberg, 1990).

An example of an organization that benefits from elevated employee perceptions of fairness is Costco. With a comparatively high average wage at $\$ 19$ per hour, zero layoffs during the recession, and 86 percent of employees receiving healthcare and benefits (although half of the workforce is part-time), there is a strong incentive for employees to reciprocate by remaining productive and loyal to the company. CEO Jim Sinegal explains, "When you hire good people, and you provide good jobs and good wages and a career, good things are going to happen". These practices have translated into a $\$ 1.3$ billion profit for Costco in fiscal 2008 (Ruggeri 2009).

Thus, the following hypothesis is posited:

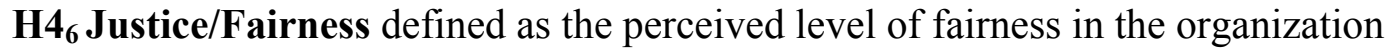




\section{$\underline{\text { Humility }}$}

Humility is a lack of arrogance and a capacity to listen carefully and without ego — which strengthens leadership competence and performance. As a leader, Aeneas was "always thoughtful of his men, comforting them when they are downcast, though he is himself steeped in sorrow, or is grieving because of the burning of his boats and the prospective separation of many of his comrades" (Hahn, 1931, p. 665). Another illustrative example occurs when Aeneas was sailing from Carthage to Italy to fulfill his destiny. When severe weather threatened their progress, he was warned by Palinurus, a lowly helmsman who called from the high deck that they were in grave danger and needed to change course for Sicily by noting: “...I could not hope to make landfall on Italy in this weather. It's thickening up, and now the wind blows hard out of the murky west abeam of us... Seeing that fortune has the upper hand, I say give in and follow where she calls" (Book V, 23-26; 31). Aeneas could have been bloody-minded and demanded the continuation of their futile journey, justified by the righteousness of the overall mission - or worse blamed the sailor for his inability. Instead of fighting the helmsmen's logic and loyal advice, Aeneas reassures him:

For some time now

I have noticed what the veering wind demands

And fought it uselessly. Change course,

Haul yards and sails around. Could any soil

Be more agreeable to me, or any

Where I would moor these tired ships,

Than Sicily, home of my Darden friend,

Acestes, and the ashes of my father? (Book $V$, 35-42)

Another way in which Virgil highlights the opposite of humility or hubris, which causes the blindness borne of arrogance, is illustrated by Aeneas' protagonist Turnus who vows that by winning in battle:

Turnus will rise

In fame to those high gods upon whose altars 
He makes the offering of his life: he'll be Alive on the lips of men (Book XII, 321-324)

But Turnus' superbus or hubris in delighting in Pallas' death had already sealed his fate, offering a cautionary tale: "The minds of men are ignorant of fate, and of their future lot, unskilled to keep due measure when some triumph sets them high" (Book X, 701-703). In this regard, effective leadership and the task of Rome as explained by Anchises is "to rule the people, but not simply to rule. More than that: to establish the ways of peace by sparing the humble and casting down the proud" (Thornton, 1953, p. 84). By these actions "Turnus' death becomes inevitable. He shows how incompatible his existence is with the terms of any truce upon which the future of the Trojans and Latins depends" (Lloyd, 1972, p. 132). As Cicero (54 BCE) cautioned regarding ceding to passion:

What can be nobler than the government of the State by virtue? For then the man who rules others is not himself a slave to any passion, but has already acquired for himself all those qualities to which he is training and summoning his fellows. Such a man imposes no laws upon the people that he does not obey himself, but puts his own life before his fellow-citizens as their law (trans. Keyes, 1928, p. 79).

We might note that superbus, pride or arrogance, is never used in association with Aeneas. His humility shines through. By comparison in the political realm of the Res Gestae, Augustus avoided such association. His promotion of his own influence (auctoritas) rather than power (potestas) (see Res Gestae, 34) as well as his constant and careful obeisance to Republican tradition distanced his person from theoretical associations with kingship, pride and personal power.

In modern leadership, the presence of humility is a key factor in transforming a company from good to great. Collins' (2001) study of Level 5 leadership explores the common traits that enable leaders to elevate companies from mediocrity to sustained excellence. Rather than the prototypical alpha male, he found that a high level of personal modesty was a recurring 
theme. When these so-called "Level 5" leaders were questioned about themselves, they would respond with statements such as "I don't think I can take much credit for what happened" and instead attributed success to either the efforts of other executives or just plain good luck. Such humility may go against the modern conception of what makes an effective leader, as a quiet and humble disposition is often viewed as a sign of personal weakness. Boards of directors are typically programmed to seek dynamic executives with larger-thanlife personalities in order to produce dramatic results. However, Collins revealed that in twothirds of comparison companies studied, it was "the presence of a gargantuan ego that contributed to the demise or continued mediocrity of the company" (p. 67).

In inevitable times of crisis, leaders need goodwill and empathy borne of humility that are critical to maintaining latitude and flexibility with stakeholders which enables organizations to constructively work through challenges. As Learned, Dooley and Katz (1959) noted, "each of us is always inadequate to the full demands of whatever situation we encounter. From each of us, then, is demanded a continuing, profound humility concerning the spiritual adequacy of our own ideas and actions" (p. 119). In 2009, for example, multi-billion dollar biotechnology company Genzyme had production for their lead drug, Cerezyme, halted by the US FDA (Food \& Drug Administration) due to chronic manufacturing problems. Initially, Genzyme announced that inventory shortages for the life saving drug Ceredase, which treats Gaucher's disease would only last 6 to 8 weeks, and leave many patients in want of needed therapy. CEO Henri A. Termeer acknowledged that the company had let patients down and stated: "We have this enormous humility...We have to re-earn our standing with these patients" (Pollack, 2010).

Another example is Jeff Immelt, CEO, General Electric reflecting on their stumbles during a deep recession in 2008. Instead of blaming economic conditions for their poor 
performance, Immelt reflected that the crisis made the multinational giant "humbler and hungrier...I needed to be a better listener coming out of the crisis. I should have done more to anticipate the radical changes that occurred. [I] did things I never thought I would have to do. I'm sure that my board and investors frequently wondered what in the heck I was doing" (Glader, 2009).

Thus, the following hypothesis is posited:

H4 $_{7}$ Humility--lack of arrogance, capacity to listen carefully, and egolessness--strengthens leadership competence and performance. 


\section{Sense of Urgency}

A sense of urgency is the capacity to instill an immediacy or action-orientation to achieve results. This is an aspect of the Aeneid that may appear on the face of it as somewhat lacking. The divine purpose of the poem spans a thousand years from Aeneas to Augustus. Nevertheless, Aeneas can act with urgency when the situation calls for it and once he has resolved on a purpose. His departure from Carthage is an excellent example (Book IV, 28690). A critical theme in the Aeneid is that "true courage, not the honours of politics, courage takes by storm that immortality which is denied to me" (McGushin, 1964, p. 246).

Have we not known hard hours before this?...

God will grant us an end to these as well...

Now call back your courage, and have done with fear and sorrow.

Some day, perhaps, remembering even this

Will be a pleasure. Through diversities

Of luck, and through so many challenges

We hold our course for Latium (Book I, 271; 273; 275-280)

...But by their deeds to make

Their fame last: that is the labor for the brave (Book X, 653-654)

From a modern leadership lens, establishing a sense of urgency has become an essential component of enacting organizational change in an ever-changing environment. In order for change to occur, employees must be convinced that immediate action is necessary for the benefit of the organization. Kotter (1996) described two types of urgency that leaders can create. The first is born of fear, panic, and complacency with the status quo - and is ultimately counterproductive to reaching an organization's goals. The second leads the organization to real and lasting change. Kotter explains, “true urgent leadership doesn’t drain people. It does the opposite. It energizes them. It makes them feel excited" (p. 97).

An example of extreme, urgent leadership is shown through the government appointed chief executive of General Motors, Edward Whitacre. Whitacre was charged with the 
monumental task of returning the company to profitability and repaying billions of dollars in federal bailout money. Zealously, he began cutting and shortening meetings, casting aside stacks of Powerpoint slides, and decentralizing decision making. He proclaimed, "We need to hurry every chance we get. This is about a turnaround, this is not business as usual. This is about a new GM, a new way of doing business" (Green, 2009, p. 1).

Another example is the policy of former vice president of Levi Straus, Tom Kasten, to show employees videotaped interviews with customers (Dess \& Picken, 2000). According to Kasten, "One big customer said 'We trust many of your competitors implicitly. We sample their deliveries. We open all Levi's deliveries.' Another said 'Your lead times are the worst. If you weren't Levi's, you'd be gone"” (p. 22). Such comments were a compelling wake-up call for the company, thus creating a pressing atmosphere promoting the urgent need for change. Kasten recounts of the tactic, "It was powerful. I wish we had done more of it" (p. 22). In a broader context, Katzenbach (1997) found:

Top executives must create and maintain a sense of urgency about resolving those issues that are critical to overall company performance. A team mobilizes around a meaningful purpose and a commitment to specific, common goals, a team's purpose and goals may be important without being either urgent or critical (Katzenbach, 1997, p. 87).

Thus, the following hypothesis is posited:

$\mathrm{H4}_{8}$ Sense of urgency is the capacity to instill a sense of urgency or action-orientation to achieve results

The leadership themes of vision, culture and values coded above from the Aeneid are aligned with the Roman ideals of fatum, pietas, and virtus. These values-based leadership themes were transformed into eleven structured, open-ended interview questions (see Appendix A). In turn, the research questions were used as the basis for qualitative and quantitative interviews with a diverse set of multi-sectoral (i.e., for-profit, non-profit, government) leaders to explore their relevance to modern leadership. In addition, participants 
were provided a set of randomly sorted index cards with each of the eight values or virtusintegrity, good judgment, leadership by example, decision-making, trust, justice/fairness, humility, and sense of urgency — and were asked to rank them from most important to least important in terms of influence on organizational performance. The results of the interviews and rankings will be reviewed in the next section. 


\section{Results}

Using the key values-based leadership themes from the Aeneid which were coded in the prior section, a diverse group of leaders from several sectors of society were interviewed to explore the potential level of relevance of the epic to the challenges of modern leadership. In this case, leaders from across for profit, non-profit and government sectors (e.g., CEOs, judge, university presidents, religious clergy, physicians, military officers, museum director) were interviewed to ensure a broad representation. The interview responses were anonymized per ethics protocol to ensure openness and are noted with the following legend: Education (E), For Profit (FP), Government (G), Judicial (J), Non-Profit (NP), and Spiritual/Religious (S). These structured, open-ended questions are grouped into three themes-vision, culture, and values.

\subsection{Qualitative Results}

\subsubsection{Vision}

Based upon the analyses from the previous section, it was posited that a compelling vision, larger than any individual, is necessary for organisational success and sustainability. Therefore, the following question was posed to the leaders:

To what extent is a compelling vision that is larger than any individual necessary for organizational long term success? If so, what are the essentials of a compelling vision?

The following is a representative sample of responses. Several leaders highlighted the importance of seeking benefits for a broad range of stakeholders.

S: There needs to be a vision above and beyond the immediate work that people do and... something that helps a wider community. It's not just me getting rich but it's a wider community being enhanced... and that also means taking into consideration the long-term implications of what we are doing today, so that the future is enhanced and not impaired.

NP: Over time a vision sort of evolved, a mission statement evolved, that not only combined the interests of several key players, early on in the history of this institution, but we also looked beyond ourselves, developing this mission by embracing this vision that 
we were serving an important function not only within the community, but also within the region.

S: Our vision has two essential goals: (1) living the devoted life to God and service, and (2) and working collectively within their community.

NP: Vision creates a foundation ... a purpose for individual and organizational legacy. It must be articulated and tested and goes beyond the individual.

FP: Compelling vision defines what we are doing today, how the stakeholders are engaged, and the necessity of inseparability between today and tomorrow.

Other respondents focused on the value of communicating an easily comprehensible message in order to create meaning and order within an organization.

G: I think the key is long-term success. I think you have got to have a cause that is greater than your own self-interests to have long-term success for an organization or for any type of movement.. You may have different ideas about how to realize that vision, but I think it's got to be clear to at least the majority of the people in the movement or the organization. People need to articulate the vision to others in simple terms that are understandable.

E: A simple, clearly understood mission statement...of the purpose of the institution ... people need to be reminded of it almost constantly.

$J$ : Vision is necessary to operationalize the judicial branch of government. It establishes a set of principles to operate from and creates an impact on other government branches. The three principles are: (1) good steward of resources, (2) respect and understanding of the limited role of the court, and (3) promote public access to unbiased justice.

Finally, leaders emphasized the power of a compelling vision to motivate and inspire members of an organization.

NP: Without organizational vision it is impossible to connect individual and organizational motivation.

E: Vision matters for long-term success as it coalesces around organizational goals. It is necessary to strengthen an understanding of what really matters, and frames the strategic plan. The leader doesn't drive the process, but engages others to encourage buy-in.

FP: Vision is a direct and highly causal ingredient for long-term success, especially in business. It creates energy, sacrifice, commitment, and inspiration for organizational purpose...Instilling values that are more noble and meaningful than individualistic ones. 


\subsubsection{Culture}

From the previous section, it was concluded that a founding story is important to

communicating and influencing organizational culture. Therefore, leaders were asked:

What is the importance of a founding story (e.g., Nike CEO Phil Knight, a middledistance runner who turned selling shoes out of his car into a footwear-and-apparel colossus, Book of Genesis in the Bible, Dell Computer's founder Michael Dell starting with \$1,000 in his University of Texas dorm room) in communicating and influencing organizational culture?

One theme that emerged was the involvement of external stakeholders and how they are

affected by an organization's culture.

NP: The cultural foundation creates a common identity reflecting in our case the civic diversity (life of the city) and our museum, and a partnership with the public and our membership.

J: The courts have a strong internal culture. This is necessary as it denotes the constitutional purpose and responsibility of the courts, and gives trust and confidence to the public and other government branches. It is essential that the public see the competence and impartiality of the courts.

Other leaders focused on the capacity of culture to guide decisions and enact change.

$G$ : When there is a lack of understanding and clarity regarding organizational vision, you can always go back to the founding story and kind of base it on.... What would the founding fathers do.....or what would the founding CEO have said about this? What were his ideals? What did he have in mind?' I think that kind of keeps all the focus glued together [and provides] direction, clarity and guidance.

S: Family type of culture. We as a community determine what type of leader we need every four years, and the leader is bound within obedience as a central foundation. Our obedience has central understandings of community, conservativism, reasonableness, and mutuality as a framework.

FP: The hospital recently underwent a transition from a culture reflective of a bureaucratic state agency to a service/advancement and organisational form. The culture frames getting the 'right people on the bus'. We focused on changing the CEO, and moved towards a service/performance success framework and away from the historically seniority-based system.

Lastly, the theme of creating energy and purpose within an organization was highlighted. 
E: The founding story brings to light a branding issue. It is good to know the historical narrative and history...it helps to create a shared sense of mutuality and helps to acquire organizational purpose.

FP: Similar to vision... a strong culture is highly useful, but not necessary depending on if the leadership is skillful in communicating. Initially it energizes the organization through the founder, and overtime its forms the cultural basis and understandings.

Next, the leaders were asked:

\section{Are symbols and/or rituals (e.g., all ranks of military personnel break hierarchy to salute Medal of Honor recipients, singing of national anthems such as the Star Spangled Banner at sporting events, Nobel Prize for advancement of a discipline) important in creating a cohesive organizational culture?}

Several respondents cited the power of symbols and rituals to help an organization fulfill its mission and goals.

E: Symbols and rituals give a shared sense of identity and of purpose... and they also mark moments of importance and transition and are important for that reason. Their connection to the founding story is compelling. Symbols and rituals are important for reinforcing an awareness and value of the central mission. That's why they are effective because it reminds people that we share a particular goal, a particular set of objectives, and that we are all invested in performing as well as we can to fulfill those shared goals.

S: Every culture, religious tradition, and organization has those stories. There's a sense in which you need to return to that story from time to time to touch base with the creative power of the beginning...you go back and tell the creation story again to remind people of why they are here, who the Creator is, and all that. But, even in the founding stories of countries, and the founding stories of cultural traditions, something essential is included in those stories and they become a touchstone for continuing....Also, symbols of a tradition that can remind folks of who they are and where they're supposed to be. Rituals are the sort of representation of the drama of the tradition. For example, in the State Government... you begin with the flag coming forward before the House of Representatives meets and somebody offers a prayer, and the gavel comes down and the session is called to order. There's a regular routine which harkens back to the beginnings of parliaments...which creates a strong culture.

J: Symbols and rituals are important in an atmosphere of impartiality - the rule of law protects the individual. The courts need to change with society, and can't just sit back and wait for disputes. The courts need to engage the public to reinforce the court's legitimacy and demonstrate that law protects the individual.

G: The symbols are visual...for the military, it is usually a flag or an emblem. In addition to that, there are a lot of cultural things that we will do out of tradition, such as different customs and courtesies, as well as salutes and formations that are the nature of military protocol. These things are customary and what they do is help promote indoctrination; 
they help remind everybody what our purpose is in relation to organizational goals. What we are here to protect and what we stand for.

S: Rituals and symbols are important in creating order within our Order. We are a community of equals in the service of God and the community. The leader listens and informs the community, and holds the place of Christ and expresses the will of God (not one's own will) for the community.

Also, the theme of symbols as mechanism for empowering, rewarding and reinforcing culture was cited:

NP: Creating a culture where people feel comfortable, people feel empowered, people feel a strong sense of self-worth, working towards a common set of goals is good and right.

FP: Stories do seem to matter. I think stories are critical in communicating and influencing a culture for both good reasons and bad reasons. The good reason for which stories are helpful is that as humans, we speak with our limbic system and tend to remember things better and more completely when they are in a story. And when we like that story, it helps us as an effective communication tool.

NP: We incorporated excellence awards to define clinical excellence and quality. This was purposeful to transform from a tenured based culture. We wanted an identity as a knowledge and management driven hospital. 
4.1.3 Values-based leadership has been defined as the moral foundation underlying stewardship (e.g. performance, sustainability, societal good) decisions and actions of leaders. Respondents were asked questions regarding each of the eight coded values or virtusintegrity, good judgment, leadership by example, decision-making, trust, justice/fairness, humility, and sense of urgency.

Integrity: Integrity was defined as the steadfast adherence to a strict moral or ethical code. Thus, the leaders were asked: does integrity impact leadership effectiveness, and to what degree? (personal value)

Some respondents discussed the role integrity plays in making decisions in the face of opposition.

FP: Morality is the kind of thing where there is no partial credit. You are either doing it or you are not. In general, people should never do something that they find morally objectionable, no matter what the chain of command says. And there is no excuse. But, for the sake of pragmatism, sometimes you have to do things that you don't agree with. You have to just disagree and commit. In other words, it is not a moral issue. It is like, "You know, I think their strategy sucks. And I've made my objections known, but, at the end of the day we all voted and that is the strategy we're going to do. So I'll get behind it and do my best even though it's not what I wanted us to do." Sometimes, you just have to disagree and commit. But, if it is a moral issue I don't think anybody has to make any compromises.

NP: Integrity has driven me throughout my entire professional career. I believe that it has made me an effective leader because my staff knows that I have high moral and ethical standards, and that I will not cross certain lines. I have lost jobs for that. 25 years ago, I was a director at a Museum of Art in California. My Board of Trustees at the time was involved in a number of, unbeknownst to me, unethical and illegal practices. They had basically taken out a substantial line of credit to get them through some rough times. Then they wanted to take the permanent collection and sell it off to retire their debt, where they should have been out raising money to retire the debt in the first place. Basically I had taken a moral and ethical stance, and I had a five year old son and my wife was pregnant with her second child... and I got fired. Integrity is absolutely important and is central. You have got to be able to go to sleep at night. You better be able to look yourself and say "Everyday, I try to make the right decisions".

Others highlighted the importance of consistency.

G: If you're perceived as corrupt, it doesn't whether you are doing the right thing. If your image and reputation are blemished because you lack integrity in other areas, then you're basically like a hole in a ship. You have a hole and you are taking out the water 
but you are still sinking. It doesn't matter that the top side of the ship looks like it is in great shape. There is a hole under the water line and the ship is going to sink.

NP: Every day leaders are measured and challenged, and your word is your bond.

Without the leader's integrity and honesty there is no ability to have trust or fairness.

Finally, the leaders detailed the relationship between integrity and organizational buy-in, support, and commitment:

FP: Without integrity leadership is completely compromised. You can't expect people to take risks in a group or organization. If you cannot believe in the leader then it immobilizes and paralyzes the organization.

NP: Lacking integrity within the leader or organization dilutes the value of the institution and makes it ineffective.

NP: The people we serve and the donors who give us resources rely on us to have integrity, which is a key value in the services we provide to those in need.

J: The public must have trust and confidence in relying on the justices and the courts; believing we are beyond public and private pressure.

NP: Integrity is number one on my list and the key value for leadership. Without it as a foundation, people will go not support the organization and we will have dead end results.

S: One cannot be respected and represent authority without integrity. How can one represent the Holy Spirit if the leader lacks integrity as an essential value? 
Good judgment: It was determined that good judgment, tempered by flexibility and situational awareness, significantly influences performance. Therefore, the leaders were asked: to what extent does good judgment, tempered by flexibility and situational awareness, influence performance? (personal value)

Respondents highlighted the importance of gathering the opinions of others when making a decision.

NP: I try not to make rash decisions. I often try to sit back and think about what that decision might be and weigh the pros and cons, good or bad...I'll make a decision and then, if, once I made that decision, someone might report, "Maybe this part of the decision wasn't right." It's [also] about being flexible, and listening to others and trying to make informed decisions...it's not waffling, but rather trying to do the very best and trying to make the very best decisions for the institution.

S: Requires delegating to others within the community, and relying on others for their experience and knowledge. Good judgment must focus on quality input from others.

Additionally, the leaders emphasized removing personal biases to promote a positive organizational image.

FP: Good judgment is an optimal characteristic that makes good leaders. It's necessary to incorporate the facts and experience, and avoid personal preferences or insecurities.

J: Good judgment is essential for the public to embrace the competence of the court.

Finally, the pattern of making mistakes and adjustments was discussed.

G: Who knows it is bad judgment until the act has passed? Hopefully, leaders make decisions using their best judgment. If it turns out, in hindsight, that it was poor judgment, individuals can tolerate that in a leader to a certain extent. But if it becomes epidemic, or there is a series of bad judgments, I think that is when the leader fails.

NP: Good quick decisions and then move to correct is available, which goes hand-inhand with decision making.

NP: Good judgment is essential with the knowledge that not everyone is perfect. Depends on having the right personal and organizational DNA.

FP: Good judgment doesn't mean making a decision and sticking with it no matter what. Good judgment means you know when to stick with a decision and when to recognize that circumstances have changed. 


\section{Leadership by example: Leadership by example was defined as the collective actions, decisions and general deportment of leaders. Therefore, the following question was posed to the leaders: Does leadership by example (e.g., personal sacrifice) enhance leadership effectiveness? (organizational value)}

A key theme that emerged was the notion of only requiring a follower to do something that a leader would do themselves.

NP: I think my staff knows that there's nothing that I wouldn't do here... if it involves staying late, coming in on weekends, taking work home, whatever it is: they know that I want what is best for this institution. That's the way I lead and I think they are the same way. It's just because of the nature of my background and how I came up through the ranks. I've done just about everything within a Museum, from schlepping art around, picking up art, delivering art, writing budgets, writing grants, developing education programs, lecturing, and installing artwork. I've done a lot of the things that my staff does, so I'm familiar with what it takes to do that work.

G: Try to never ask anyone to do anything until you do it yourself: whether that would be jumping into the water after somebody or just minor day-to-day tasks. Is it because you don't want to do it or because you need to delegate? If you are giving it to somebody because you don't want to do it, not because it is the right delegation, then I don't think that is a leadership trait. Leadership by example means you are doing the things that you expect your subordinates to do.

Additionally, the leaders underlined the value of becoming a model to guide the actions of followers.

FP: The higher up the chain-of-command the more important is leadership by example. When the leader is more remote from the day-to-day activities, they become less valued for tasks and more valued by image. They are required to create an example of what is the right thing to do. You are the 'embodiment of the organization.'

NP: When you lead by example you represent the values those around you access.

NP: The position of the leader is to represent the standard that others are to follow.

$\boldsymbol{S}:$ With new members it is key for there to be a role model for other members. They need to see the importance of living one's life with everyone else.

Lastly, respondents categorized leadership by example as a vehicle for building trust and respect within an organization. 
NP: It is necessary to be genuine within the institution. The key in our case was to rebuild the trust within the institution, and I focus on being transparent to all within the University.

NP: Leadership needs to reflect the sacrifice that others are making given the high risk areas of deployment.

S: Leadership entails... making bigger sacrifices and living at a basic level of ethical values. Political leaders, for example, that have screwed up in their personal lives which everybody sees and yet, they assume it doesn't matter.... but when they do that, they are less able to lead because they lose the respect of their staff and community. 
Decision-making: Decision-making was defined as the steadfast adherence and support of directives that follow the chain of command, unless requested actions are immoral, illegal or unethical Thus, the leaders were asked: Is steadfast adherence and support of directives that follow the chain of command, unless requested actions are immoral, illegal or unethical, important for organizational success? In other words, does the public responsibility of good leadership outweigh private preferences and/or benefits? (organisational value)

The ability to analyze large quantities of information and quickly act was a key theme among respondents.

S: The best leaders are the ones that can be decisive, but who can also listen and understand when they are getting even contrary, but excellent ideas.

G: If you don't have solid decision-making on the smaller tasks, then you can't ever move on from each of the milestones and get to your overall goal. It sounds very simple, but sometimes we get hung up in a lot of analysis, trying to get perfect information and people won't make decisions without perfect information. So, as a leader, you have got to be able to act on information that is imperfect.

Also, several leaders stressed the importance of determining what is in the best interest of the organization when making a decision and holding firm to that directive.

E: You have an obligation to the institution that overrides your personal interests. Sometimes, you have to do things that are unpleasant and cause you pain, although for the good of the institution.

FP: Decision making is critical in larger organizations where a large number of individuals need input and direction. It exposes the group to a point-of-view, and once the decision is made you need to embrace the directive. When collaborating in small groups it is necessary to act together to enhance steadfast adherence and support.

NP: Decision making requires shared sacrifice, listening, and trying to understand what is happening. One must focus on behaviors and not rules and policies, or regulations. Many decision makers make the mistake of imposing, instead of leading to actions that are best for the institution.

Lastly, the significance of accountability in decision making was stressed.

NP: In decision making, it's very important to utilize a line of authority ... someone has to be responsible.

J: Decisions carry tremendous weight to the public. The court decisions need to be in plain English, and be guided by ensuring those that needed access to the court got it; the 
Is The Aeneid Relevant to Modern Leadership?

decision was communicated clearly and was transparent; those parties and the court are accountable; and the court is engaged with the public.

NP: Good decision making requires participation within and without the team ... by incorporating a model that continues to challenge each decision and requires mutual accountability. 
Trust: Trust was defined as relationship of reliance between leaders and followers. Therefore, the leaders were asked: How does trust, or distrust, impact organizational performance? (personal value)

Many respondents linked trust with motivation and organizational commitment.

G: I rank trust and integrity together, and distinct from competence. If I am flying with a helicopter pilot, for instance, if I don't trust that that person is competent, then that is ultimately going to affect my mission performance even though it is not related to flying. I have to trust that the organization trained the individual to fly the aircraft and I have to trust that the individual is acting in the manner that they were trained to act.

S: Launching forward on a particular program, if I don't trust that a person has intelligence, foresight, and ability - then I'm going to be unwilling to follow. If I don't trust that the person doesn't have my best interests, as well as the best interests of the organization and community at heart, then I'm going to be less than happy about following as well. If I didn't trust a leader I would, at the very least, hang back and not put in the effort that I might otherwise do. And if there was no issue of trust between me and my director or my boss, I would work much harder and with much more energy.

NP: If you are asking someone to do something, they need to know they are sacrificing for the right reason ... they are investing themselves in hope and time.

NP: Trust cements our community.

Others alluded to the damage that a lack of trust can cause.

J: What would happen to society if the public lost trust in the Judicial branch. The implications and significance would be profound. Courts have to maintain the respect and trust of the public, and know they are beyond any pressures and personal self interest.

NP: Without it you're out of business...literally.

Finally, the leaders described the necessity of time and patience when building trust.

NP: Every single day you engage others, and you earn trust very slowly over time, and then all of a sudden it can be lost in a moment.

S: It took two years for many within our community to trust me as the leader. I was reluctant to speak up and put myself above others, but I realized that that was one of my responsibilities...speak up when necessary and always listen. 


\section{Justice/Fairness: Justice/Fairness was defined as the perceived level of fairness in the organization. Thus, the leaders were asked: How does the perceived level of organisational justice or fairness effect organizational effectiveness? (organisational value)}

A number of leaders detailed how justice and fairness is connected to dedication and sacrifice

within an organization.

FP: Human beings in general respect and expect to be treated with justice and fairness. It is corrosive of service and general operations if issues are dealt with in an unjust way. If decisions are beloved to be unjustly exercised it compounds ineffectiveness.

FP: There has to be a very high perception of justice and fairness for people to get involved. I don't think it's just a perceived level, it has to be an actual level.

G: You can make a lot of decisions and people are not happy with the decisions but I think it has to perceived as fair. That's the bottom line. You can make the right decision a hundred times, but if people involved don't perceive it as fair or perceived it as a biased or corrupt method of getting there, then even if it is the right answer, the results seem to be questioned always. People will accept, a lot of times.... they may not like the decision to you came to, but if they perceive it as just or fair, they are willing to accept it.

NP: When people sacrifice within an organization they have to believe that they will be treated in a fair and just manner.

S: We have a community of caring for one another, and no member can act in a manner that is in fact or perceived as unjust or not fair.

Other leaders tied justice and fairness to external customer perceptions of an organization.

NP: Within our organization, justice and fairness are critical components of our organizational effectiveness. We operate in high risk countries and many employees are at personal risk and those they provide services to need to believe that what we do is in their best interest.

J: A key cornerstone to the public believing in the institution of the law. We [as Judges] need to represent a key principle of impartiality and that the rule of law protects the individual. 


\section{Humility: Humility was defined as lack of arrogance, capacity to listen carefully, and egolessness. The leaders were asked: Does humility strengthen leadership competence? (personal value)}

Several respondents cited the tendency of a leader's arrogance to turn followers away from

the leader and/or the organization.

$E:$ My sense is that if the people who are following don't see humility, even to the point of vulnerability, in their leader, that they won't take seriously that person's commitment. It enhances the compelling arguments of the leader if people listening know that this is a person who has examined his/her own doubts and uncertainties and come to the conclusion that this is the right path. If there is a sense of arrogance that, "I must be right by virtue of simply who I am", that diminishes the argument of the leader.

NP: It is essential to be humble, as arrogance would likely kill our organization; it wouldn't be effective and worthy of continued sacrifice and support.

J: Decisions affect many within our community, and a judge must rely on a calm and measured approach.

G: If you are not humble, especially in the military line of work, you will be humbled very quickly. It is absolutely something that everybody expects.

Additionally, great emphasis was placed on patient listening and giving credit to followers.

S: Within our order humility is an absolute necessity. Arrogance gets you nowhere - and humility is a virtue that allows those within our order to contribute through listening and engaging all others.

NP: Being willing to listen and being open to your staff just creates a better organization. It's all about communication. As a leader, it is about being comfortable with who you are and what you bring to the table, and being open to the staff's suggestions.

NP: The leader must give people the permission to challenge her; this allows for the best ideas and community needs to be expressed.

FP: Humility is extremely important in leadership. Because humility.... forces people to listen carefully. Otherwise, arrogance turns off people's receptors to data. Humility is good in a personal sense, but in terms of a practical sense if you are not humble you may not be listening, and if you are not listening then you are not being effective. 
Sense of urgency: Sense of urgency was defined as the capacity to instill a sense of action-orientation to achieve results. Therefore, the following question was posed: To what extent does the capacity to instill a sense of urgency or action-orientation to achieve results impact leadership effectiveness? (organisational value)

The value of enabling an organization to quickly react to its environment was a key theme in many of the responses.

FP: Understanding urgency makes a good manager great. Urgency is the energy that is transferred from leader to followers. Without it the organization becomes stagnant and it ends in the law of unintended consequences.

NP: Our mission is to respond to enormous crises, and when we respond to these we must respond quickly and decisively. We need to operationalize the maximum relief possible.

Notwithstanding, several of the leaders also indicated the need for caution when inducing urgency into the organisation.

G: Sense of urgency is a little more difficult because it can be used very effectively to get things done in a timely fashion and to get everybody focused. At the same time, you can very easily be called 'the Boy who cried wolf'. You can't create a sense of urgency around every minor event just to get things done. You need to make sure you focus the sense of urgency around issues that are vital or essential.

S: We are well established, very measured, conservative, and need to be cautious in any new direction.

NP: One needs the right combination of patience and impatience. You don't want to be too driven, as it creates resentment, but as the leader you are still accountable for the results. 


\subsection{Quantitative Results}

To triangulate on the qualitative results (Jick, 1979), at the end of each interview multisectoral leaders $(\mathrm{n}=13)$ were provided a set of eight, randomly sorted index cards with each value - integrity, good judgment, leadership by example, decision-making, trust, justice/fairness, humility, and sense of urgency — and were asked to rank them from most (1) to least (8) important as shown in Table 2 (Yoon \& Hwang, 1995; Louviere, 1988; Green, Krieger, \& Yoram, 2001).

\begin{tabular}{|c|c|c|c|c|c|c|c|c|}
\hline Value Type & Personal & Personal & Organizational & Organizational & Personal & Organizational & Personal & Organizational \\
\hline \multirow{6}{*}{$\begin{array}{l}\text { Sector } \\
\text { Education } \\
\text { Education } \\
\text { For Profit } \\
\text { For Profit } \\
\text { Government }\end{array}$} & Integrity & $\begin{array}{c}\text { Good } \\
\text { Judgment }\end{array}$ & $\begin{array}{r}\text { Leadership } \\
\text { by Example }\end{array}$ & $\begin{array}{l}\text { Decision } \\
\text { Making }\end{array}$ & Trust & $\begin{array}{c}\text { Justice/ } \\
\text { Fairness }\end{array}$ & Humility & $\begin{array}{l}\text { Sense of } \\
\text { Urgency }\end{array}$ \\
\hline & 1 & 2 & 4 & 5 & 3 & 6 & 7 & 8 \\
\hline & 1 & 3 & 7 & 4 & 6 & 5 & 8 & 2 \\
\hline & 1 & 2 & 7 & 5 & 3 & 4 & 6 & 8 \\
\hline & 4 & 3 & 7 & 2 & 5 & 6 & 8 & 1 \\
\hline & 1 & 5 & 2 & 3 & 7 & 8 & 6 & 4 \\
\hline \multirow{2}{*}{$\begin{array}{l}\text { Government } \\
\text { Government }\end{array}$} & 1 & 4 & 6 & 5 & 3 & 2 & 8 & 7 \\
\hline & 2 & 4 & 1 & 6 & 7 & 5 & 3 & 8 \\
\hline \multirow{3}{*}{$\begin{array}{l}\text { Non-Profit } \\
\text { Non-Profit } \\
\text { Non-Profit }\end{array}$} & 1 & 7 & 4 & 3 & 6 & 2 & 5 & 8 \\
\hline & 1 & 3 & 5 & 2 & 4 & 7 & 8 & 6 \\
\hline & 1 & 4 & 7 & 5 & 2 & 3 & 6 & 8 \\
\hline \multirow{3}{*}{$\begin{array}{l}\text { Spiritual } \\
\text { Spiritual } \\
\text { Spiritual }\end{array}$} & 1 & 4 & 3 & 6 & 2 & 5 & 7 & 8 \\
\hline & 2 & 4 & 1 & 5 & 6 & 3 & 7 & 8 \\
\hline & 2 & 5 & 1 & 7 & 6 & 7 & 4 & 8 \\
\hline \multirow{6}{*}{$\begin{array}{c}\text { Sum } \\
\text { Mean } \\
\text { Median } \\
\text { Mininum } \\
\text { Maximum } \\
\text { Std Dev }\end{array}$} & 19.0 & 50.0 & 55.0 & 58.0 & 60.0 & 63.0 & 83.0 & 84.0 \\
\hline & 1.5 & 3.8 & 4.2 & 4.5 & 4.6 & 4.8 & 6.4 & 6.5 \\
\hline & 1.0 & 4.0 & 4.0 & 5.0 & 5.0 & 5.0 & 7.0 & 8.0 \\
\hline & 1.0 & 2.0 & 1.0 & 2.0 & 2.0 & 2.0 & 3.0 & 1.0 \\
\hline & 4.0 & 7.0 & 7.0 & 7.0 & 7.0 & 8.0 & 8.0 & 8.0 \\
\hline & 0.9 & 1.3 & 2.5 & 1.6 & 1.9 & 2.0 & 1.6 & 2.5 \\
\hline
\end{tabular}

Table 2: Descriptive Statistics of Rankings by Multisectoral Leaders

Next, a one-way ANOVA (Analysis of Variance) procedure was performed to test the differences in mean scores between the eight coded values (Rossi, Wright \& Anderson, 1983) using SPSS v.16 statistical software. In this case, since the data do not reach assumptions of normality, a ranked transformation, one-way ANOVA is applied (Conover \& Iman, 1981) using a Kruskal-Wallis test, non-parametric method for testing equality of population 
medians among groups (Easterby-Smith, Thorpe \& Jackson, 2008). Thus, the null hypothesis $\left(\mathrm{H}_{0}\right)$ posits that the mean scores $(\mu)$ of all $(n)$ eight values are equivalent or:

$$
\mathrm{H}_{0}: \mu_{\text {value } \mathrm{n}}=\mu_{\text {value } 1 \ldots 8}
$$

Of note, quantitative results support qualitative findings in that three values - Integrity, Humility and Sense of Urgency — were found to be statistically significant $(p=0.01)$ outliers versus all other values. As shown in Figure 10, Integrity was significantly more important than all other values; and Humility and Sense of Urgency was significantly less valuable than all other values. By comparison, Good Judgment, Leadership by Example, Decision-Making, Trust, and Justice/Fairness were seen as equally important.

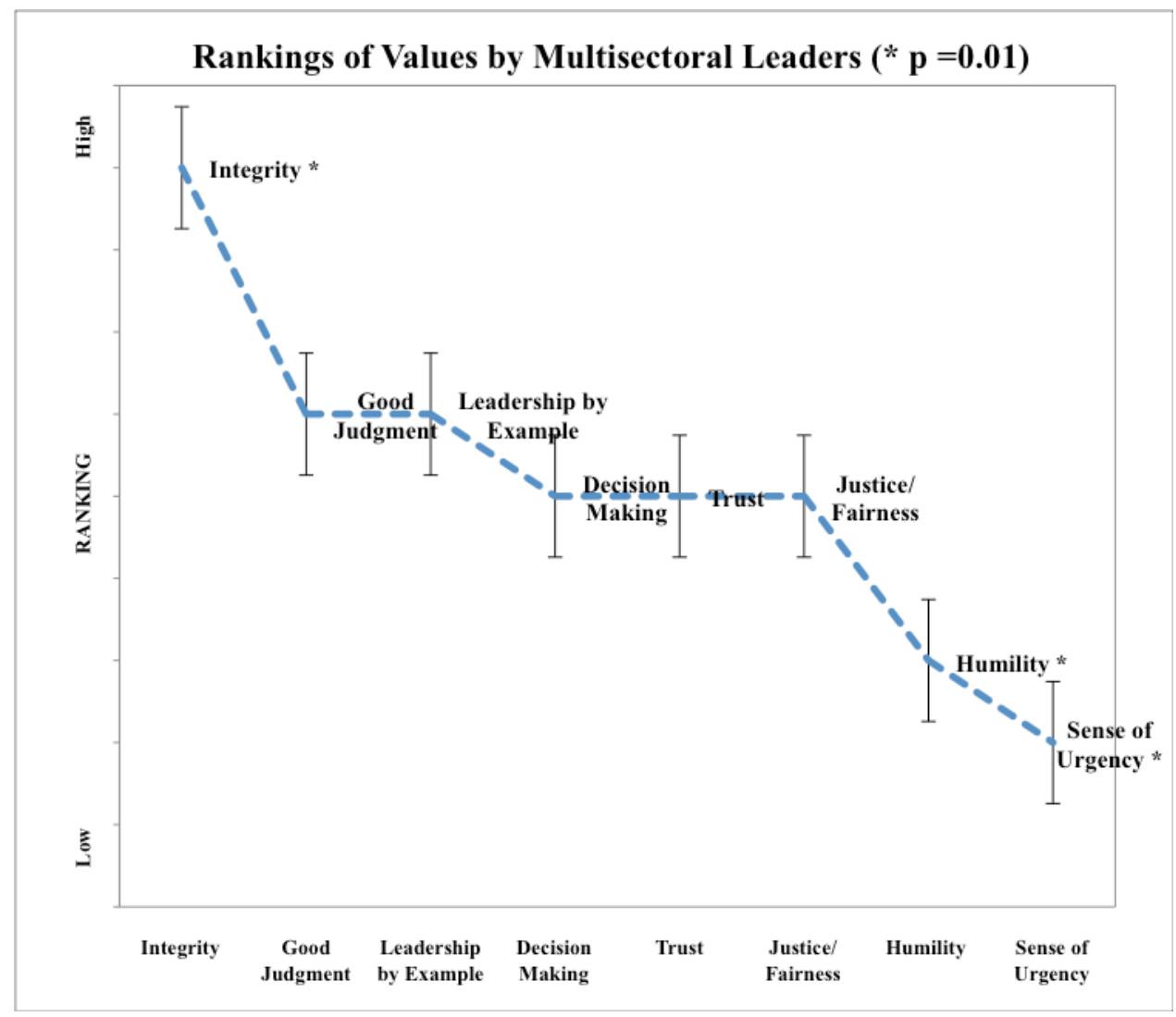

Figure 10: Rankings of Values by Leaders 


\section{Conclusion}

Far beyond transmitting the worn standard diatribe of stoic Greco-Roman values, the Aeneid illustrates the universal tensions and tradeoffs facing leaders amidst changing circumstances, situations, and availability of resources. Far beyond being wooden and moralistic, Virgil adjures leaders to reflectively struggle with inner conflict and growth as they decide on what changes to seek and to what moral foundations they must be steadfastly adhere. Far beyond simply promulgating a celebratory, self-aggrandizement of the Augustan regime, the Aenied echoes an arching vision of the Roman imperium which is rooted in the rule of law and climbs to the highest aspirations of mankind's advancement.

This thesis has examined and presented the relevance of the Aeneid to the demands of modern leadership. In juxtaposition with the assertion by some modern leadership experts that contemporary demands, wrought by forces such as globalization and telecommunication, reduce the value of studying the past, this study explored the following questions: Does modern context change the nature of effective leadership over time? Are there any fundamental human values that stand the test of time? Does a values-based leadership approach answer the timeless need for leaders who are inherently Protean: able to adapt and respond to new circumstances as they arise? That is, instead of seeking a single, once-for-all solution, does leadership which fosters and manages a dynamic tension between focus and coordination, between the ongoing tasks of external and internal analysis (with its tendency to explode current expectations and assumptions), and the need to devise and implement responses to those findings in such a way that both utilizes most effectively - and also inspires the confidence and enthusiasm of - individuals and institutions still relevant?

To explore these questions, this study reviewed the Aeneid, the foundation work of the Latin canon, in its historical context, coded the themes of its key leadership lessons, 
employed a mixed-method research framework to juxtapose the leadership lessons identified to the demands of modern leadership, and provided implications for practioners and researchers. Using a social systems approach within the context of values-based leadership, the Aeneid was analyzed to juxtapose the resonant leadership elements of vision, culture and values - and their corresponding equivalent Roman themes of fatum, pietas, and virtusrelative to the demands of modern leadership.

First, a compelling vision, larger than any individual, was found to be necessary for organizational success and sustainability in the Aeneid, contemporary first century BCE Rome, and modern organizations. Second, nurturing the culture or the prevailing attitudes, beliefs and preferences through multiple approaches, including symbols and rituals, was affirmed to be a critical aspect of organizational leadership which is likewise shared by ancient and modern leaders. Third, the Aeneid was coded into the following eight values (seen in relation to the Roman ideal of virtus) in order of importance: integrity, good judgment, leadership by example, decision-making, trust, justice/fairness, humility, and sense of urgency. Of note, integrity was found to be the most important, essential and resonant value by far and superordinate - without which the other values are severely lessened in worth. In practical terms, each of these leadership elements and Roman themes can be reduced to three essential management questions: (1) Are we doing the right things (i.e., Do we have the right strategic vision?), (2) How do we do things (i.e., Are we nurturing a cohesive culture?), and (3) Are we doing things right (i.e., Are we abiding to a steadfast set of values which informs decision making and actions?) A summary of the leadership themes and Roman elements, leadership frameworks and practical management implications from the Aeneid are summarized in Table 3. 


\begin{tabular}{|c|c|c|c|}
\hline $\begin{array}{l}\text { Leadership } \\
\text { Element }\end{array}$ & Vision & Culture & Values \\
\hline $\begin{array}{l}\text { Roman } \\
\text { Theme }\end{array}$ & Fatum & Pietas & Virtus \\
\hline $\begin{array}{l}\text { Leadership } \\
\text { Frameworks }\end{array}$ & $\begin{array}{l}\text { A compelling vision, } \\
\text { larger than any } \\
\text { individual, is necessary } \\
\text { for organizational } \\
\text { success and } \\
\text { sustainability. }\end{array}$ & $\begin{array}{l}\text { A founding story is } \\
\text { important to } \\
\text { communicating and } \\
\text { influencing } \\
\text { organizational culture. } \\
\text { - Symbols and/or rituals } \\
\text { are important to creating } \\
\text { a cohesive organizational } \\
\text { culture }\end{array}$ & $\begin{array}{l}\text { Values are the moral foundation } \\
\text { underlying stewardship } \\
\text { decisions and actions of leaders, } \\
\text { comprised of the following } \\
\text { eight elements: } \\
\text { - Integrity, } \\
\text { - Good judgment, } \\
\text { - Leadership by example, } \\
\text { - Decision-making, } \\
\text { - Trust, } \\
\text { - Justice/fairness, } \\
\text { - Humility, and } \\
\text { - Sense of urgency }\end{array}$ \\
\hline $\begin{array}{c}\text { Practical } \\
\text { Implications }\end{array}$ & $\begin{array}{l}\text { Are we doing the } \\
\text { right things? }\end{array}$ & How do we do things? & Are we doing things right? \\
\hline
\end{tabular}

\section{Table 3: Leadership Themes and Roman Elements, Leadership Frameworks and Practical Management Implications from the Aeneid}

In its contemporary context, the findings of this study provide resonance and reflection on Augustus' genius and deft skill in finding and dynamically operating in the Aristotelian "golden mean" of transformational leadership for over four decades by exercising a timely mix of fatum (i.e., bold vision of peace, prosperity, and relentless expansion of the Roman imperium), pietas (i.e., shaping culture around traditional Roman values), and virtus (i.e., foundations of moral leadership) to build and guide society as its revered pater (father). The pax Romana was an Augustan transformation at all levels of society-political, economic and cultural. Augustus continuously nurtured the consent of the governed by paying close attention to details of administration which made the lives of average Romans better through secure food supplies, water via aqueducts, and public sanitation. Augustus solidified these advancements with successful administration and lasting infrastructure by replacing an old 
web of political patronage with a new system of competent civil service, and led by example as primus inter pares (first among equals) by emphasizing his more prosaic role as administrator. He shaped and stabilized a Roman society weathered from civil war, by becoming the guardian of traditional Roman values, a role which he used to enact a series of reforms. He emphasized law and order to attain stability, but also shaped as he was shaped by culture and through the high poetic medium of the day-epic poetry which achieved its height of art and impact as the Aeneid.

Once established in power, Augustus judiciously exercised restraint, not only in keeping his ego in check, but also in understanding and measuring the great sacrifices required to commit the blood and treasure of the empire. Further, instead of command and control via military dictatorship, Augustus developed power through his auctoritas or moral authority which was nurtured by accomplishments, financial status and largesse, marriage, military service, and a variety of good works (Galinsky, 1996). That is, Augustus displayed leadership as a polyvalent skill, requiring a steady moral compass and judicious use of power, as well as the ability to effectively and reflexively communicate, coordinate, and administer amidst changing circumstances.

In juxtaposition, whether viewed qualitatively or quantitatively — or across sectors (i.e., for profit, non profit, government) — the findings of this study affirm the unequivocal relevance of the Aeneid (and by implication Roman ideals) to the demands of modern leadership. Rather than bowing to the illusion that current trends (e.g., globalization, communication, computing) are beyond ancient insights, the sweeping epic of the Aenied is timeless and suggests:

Modern discussions of ideology generally assume that ideological programs tend to be both simplistic and repressive of alternatives. What is impressive about the Aeneid considered as a poem of national ideology is that it is neither of these things. The new 
nationhood it envisions aims at unity and harmony, but not at either simplistic partisanship or conclusiveness about its values. What is revolutionary and revisionary in the Aeneid's presentation of Roman values and the Roman task is the way the poem proposes to its readers that this program, however straightforward and unimpeachable it seems, is fraught with difficulties and traps (Toll, 1997, p. 52)

In sum, while the Aeneid extols prototypical values, the epic also instructs that truly effective leadership is not about being a monochromatic prototype. Rather, the epic reveals that the essence and privilege of effective leadership demands reflection on the dynamic relationship between the leader and the led towards a better, envisioned future. After two millennia, the Aeneid continues to hold an abiding interest whether viewed through the lens of a classicist seeking the nature of things, the romanticist drawn to the unknown where the truth is to be found, or the determined leader seeking timeless insight into the human condition amidst the relentless storms of turbulent change. 


\section{Appendix A: Structured Interview Questions}

\section{Is The Aeneid Relevant to Modern Leadership?}

Virgil's Aeneid, an epic poem about the founding of ancient Rome which depicts formative leadership themes, was analyzed and coded. A diverse group of leaders are being interviewed to explore the potential level of relevance of themes found in the Aeneid to the challenges of modern leadership. These structured, open-ended questions are grouped into three themes: vision, culture, and values.

\section{$\underline{\text { Vision }}$}

- To what extent is a compelling vision that is larger than any individual necessary for organizational long term success? If so, what are the essentials of a compelling vision?

\section{$\underline{\text { Culture }}$}

- What is the importance of a founding story (e.g., Nike CEO Phil Knight, a middledistance runner who turned selling shoes out of his car into a footwear-and-apparel colossus, Book of Genesis in the Bible, Dell Computer's founder Michael Dell starting with $\$ 1,000$ in his University of Texas dorm room) in communicating and influencing organizational culture?

- Are symbols and/or rituals (e.g., all ranks of military personnel break hierarchy to salute Medal of Honor recipients, singing of national anthems such as the Star Spangled Banner at sporting events, Nobel Prize for advancement of a discipline) importance in creating a cohesive organizational culture?

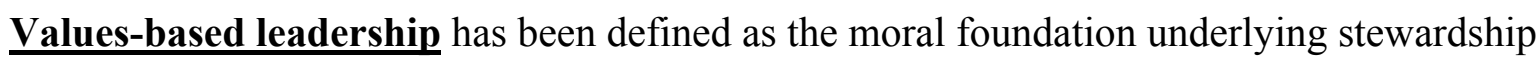
(e.g., performance, sustainability, societal good) decisions and actions of leaders.

- Decision-making: Is steadfast adherence and support of directives that follow the chain of command, unless requested actions are immoral, illegal or unethical, important for 
organizational success? In other words, does the public responsibility of good leadership outweigh private preferences and/or benefits? (organizational value)

- Leadership by example: Does leadership by example (e.g., personal sacrifice) enhance leadership effectiveness? (organizational value)

- Justice/Fairness: How does the perceived level of organizational justice or fairness effect organizational effectiveness? (organizational value)

- Sense of urgency: To what extent does the capacity to instill a sense of urgency or action-orientation to achieve results impact leadership effectiveness? (organizational value)

- Humility: Does humility (e.g., lack of arrogance, capacity to listen carefully) strengthen leadership competence? (personal value)

- Integrity: Does integrity impact leadership effectiveness, and to what degree? (personal value)

- Trust: How does trust, or distrust, impact organizational performance? (personal value)

- Good judgment: To what extent does good judgment, tempered by flexibility and situational awareness, influence performance? (personal value)

Below are the referenced values. Please rank each value in order of importance rating them from highest (1) to lowest (8) as follows:

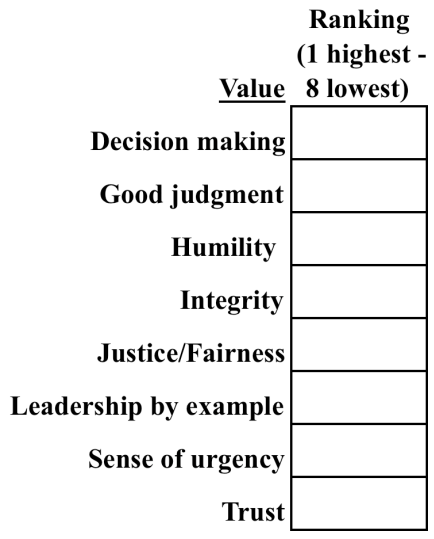




\section{Appendix B: Human Ethics Committee Approval}

\section{TE WHARE WĀNANGA O TE ŪPOKO O TE IKA A MĀUI}

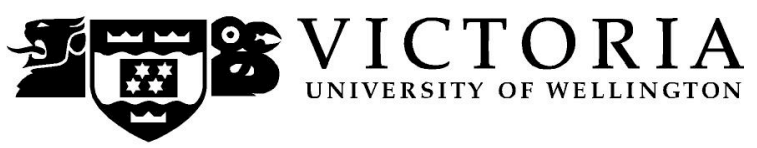

MEMORANDUM

$\begin{array}{ll}\text { Phone } & 0-4-4635676 \\ \text { Fax } & 0-4-4635209 \\ \text { Email } & \text { Allison.kirkman@vuw.ac.nz }\end{array}$

\begin{tabular}{l|l}
\hline TO & Mark Ahn \\
\hline COPY TO & Matthew Trundle \\
\hline FROM & Dr Allison Kirkman, Convener, Human Ethics Committee \\
\hline
\end{tabular}

\begin{tabular}{l|l}
\hline DATE & 17 September 2010 \\
\hline PAGES & 1 \\
\hline
\end{tabular}

\begin{tabular}{l|l} 
SUBJECT & $\begin{array}{l}\text { Ethics Approval: No } 17958 \text { Is the Aeneid Relevant to Modern } \\
\text { Leadership? }\end{array}$
\end{tabular}

Thank you for your applications for ethical approval, which have now been considered by the Standing Committee of the Human Ethics Committee.

Your applications have been approved from the above date and this approval continues until 31 December 2010. If your data collection is not completed by this date you should apply to the Human Ethics Committee for an extension to this approval.

Best wishes with the research.

Allison Kirkman

Convener 


\section{References}

Aaker, D. (1994). Building a brand: The Saturn story. California Management Review, 36(2), 114-133.

Accenture (2001). The evolving role of executive leadership. Retrieved from http://www.accenture.com.

Ahn, M., Adamson, J., \& Dornbusch, D. (2004). From leaders and leadership: Managing change. Journal of Leadership and Organizational Studies, 10(4), 112-123.

Alexander, W.H. (1945). War in the "Aeneid", The Classical Journal, 40(5), 261-267.

Anderson, C. (1997). Values-based management. The Academy of Management Executive, 11(4), 25-46

Auerbach, C.F., \& Silverstein, L.B. (2000). Qualitative data: An introduction to coding and analysis. New York, NY: University Press.

Augustus Cooley, A. (2009)., Res Gestae divi Augusti (20 AD), (A. Cooley, Trans.). Cambridge, England: Cambridge University Press.

Bass, B.M. (1998). The ethics of transformational leadership. In J. Cillua (Ed.), Ethics, the heart of leadership. Westport, CT: Quorum Books.

Bass, B.M., and Steidlmeier, P. (1999). Ethics, character, and the authentic transformational leadership behavior. Leadership Quarterly, 10(2),181-217.

Baum, H. (2005). Transparent leadership. Leader to Leader, 37, 41-47.

Becker, T. (1998). Integrity in organizations: Beyond honesty and conscientiousness. Academy of Management Review, 23(1), 154-161.

Bell, A.J.E. (1999). The popular poetics and politics of the Aeneid. Transactions of the American Philological Association, 129, 263-279.

Berg, B.L. (1995). Qualitative research methods for the social sciences (2nd ed.). Boston, MA: Allyn and Bacon.

Bloom, H. (2002). Genius: A mosaic of one hundred exemplary creative minds. New York, NY: Warner Books.

Blumer, H. (1962). Society as symbolic interaction. In A. M. Rose (Ed.), Human behavior and social process: An interactionist approach. Boston, MA: Houghton-Mifflin.

Blumer, H. (1969). Symbolic interactionism: Perspective and method. Berkeley, CA: University of California Press.

Bossidy, L. (2007). What your leader expects of you and what you should expect in return. Harvard Business Review, 4, 58-65.

Bowra, C.M. (1933). Aeneas and the stoic ideal. Greece \& Rome, 3, 8-21.

Boyatzis, R.E. (1998). Transforming qualitative information: thematic analysis and code development. Thousand Oaks, CA: Sage.

Boyatzis, R. E., and McKee A. (2005). Resonant Leadership: Renewing Yourself and Connecting with Others Through Mindfulness, Hope, and Compassion. Boston, MA: Harvard Business School Press.

Braun, V., \& Clarke, V. (2006). Using thematic analysis in psychology. Qualitative Research in Psychology, 3, 77-102.

Brunt, P.A. and Moore, J.M. (1967). Res Gestae Divi Augusti: The Achievements of the Divine Augustus. Oxford Press.

Buchanan, L. (interviewer) \& Kotter, J. (interviewee). (2009). Lighting a fire under them. Inc., 31(7), 86-90. 
Buchko, A.A. (2007). The effect of leadership on values-based management. Leadership \& Organization Development Journal, 28(1), 36-50.

Burke, C.S., Sims, D.E., Lazzara, E.H., \& Salas, E. (2007). Trust in leadership: A multi-level review and integration. The Leadership Quarterly, 18, 606-632.

Burnell, P. (1987). The Death of Turnus and Roman Morality. Greece \& Rome, 34(2), 186200.

Burns, J.M. (1978). Leadership. New York, NY: Harper \& Row.

Burns, J.M. (1995). Transactional and transforming leadership. In J.T. Wren (Ed.), The leader's companion (pp. 100-101). New York, NY: The Free Press.

Cairns, F. (1989). Virgil's Augustan epic. Cambridge, England: Cambridge University Press.

Camps, W.A. (1969). An Introduction to Vergil's Aeneid. London: Oxford University Press.

Cicero (1928). On the Republic (54 BCE) and On the Laws (52 BCE), (C.W. Keyes, Trans.). Suffolk, England: St. Edmundsury Press.

Citrin, J. (2009, Apr. 10). Learning from great leaders. Yahoo! Finance. Retrieved from http://finance.yahoo.com

Ciulla, J. (1998). Leadership ethics: Mapping the territory. In J. Cillua (Ed.), Ethics, the heart of leadership. Westport, CT: Quorum Books.

Clarke, A.K. (1947). The scope of Virgil's influence. Greece \& Rome, 16(46), 8-16.

Clarke. M.L. (1945). Rhetorical influences in the Aeneid. Greece \& Rome, 18(52), 14-27.

Coleman, R. (1982). The gods in the Aeneid. Greece \& Rome, 29(2), 143-168.

Collins, J. (2001). Level 5 leadership: The triumph of humility and fierce resolve. Harvard Business Review, 79, 66-76.

Collins, J., \& Porras, J. (1996). Building your company's vision. Harvard Business Review, 74(4), 65-77.

Collins, J.C., \& Porras, J.I. (1994). Built to last: Successful habits of visionary companies. New York, NY: Harper-Collins Publishers.

Conchie, B. (2004). The demands of executive leadership, The Gallup Management Journal. Retrieved from http://gmj.gallup.com.

Conover, W. J., \& Iman, R. L. (1981). Rank transformations as a bridge between parametric and nonparametric statistics. American Statistician, 35, 124-129.

Covey, S.M.R. (2007, June 4). The business case for trust. Chief Executive. Retrieved from http://www.chiefexecutive.net

Crabtree, B., \& Miller, W. (1999). A template approach to text analysis: Developing and using codebooks. In B. Crabtree \& W. Miller (Eds.), Doing qualitative research (pp. 163-177). Newberry Park, CA: Sage.

Cuoto, R.A. (1995). The transformation of transforming leadership. In J.T. Wren (Ed.), The leader's companion (pp. 102-107). New York, NY: The Free Press.

Denzin, N.K. \& Lincoln, Y.S. (1994). Handbook of qualitative research. Thousand Oaks, CA: Sage.

Department of the Army (2002). Decorations, medals, ribbons, and similar devices (32CFR578.4). Sec. 578.4. Government Printing Office. Retrieved from http://edocket.gpo.gov

Dess, G.G., \& Picken, J.C. (2000). Changing roles: Leadership in the $21^{\text {st }}$ century. Organizational Dynamics, 28(3), 18-34.

Dirks, K.T., \& Ferrin, D.L. (2002). Trust in leadership: meta-analytic findings and implications for research and practice. Journal of Applied Psychology, 87(4), 611628. 
Duckworth, G.E. (1945). Vergil and war in the Aeneid. The Classical Journal, 41(3), 104107.

Dudley, D.R. (1961). A Plea for Aeneas. Greece \& Rome, 8(1), 52-60.

Dutton, J. E., \& Dukerich, J. M. (1991). Keeping an eye on the mirror: Image and identity in organizational adaptation. Academy of Management Journal, 34(3), 517-554.

Dyer, R.R. (1989). Vergil's fama: A new interpretation of the Aeneid. Greece \& Rome, 36(1), 28-32.

Earl, D. (1967) The Moral and Political Tradition of Rome. New York: Cornell University Press.

Easterby-Smith, M., Thorpe, R., \& Jackson, P.R. (2008). Management research ( $3^{\text {rd }}$ ed.). Thousand Oaks, CA: Sage.

Edwards, M.W. (1960). The expression of stoic ideas in the Aeneid. Phoenix, 14(3), 151-165.

Eichholz, D.E. (1968). Symbol and contrast in the Aenied. Greece \& Rome, 15(2), 105-112.

Faber, R. (2000). Vergil's 'Shield of Aeneas' and the "Shield of Heracles". Mnemosyne, 53(1), 49-57.

Faules, D.F. \& Alexander, D.C. (1978). Communication and social behavior: A symbolic interaction perspective. Reading, MA: Addison-Wesley.

Fernandez, J.E., \& Hogan, R.T. (2002). Values-based leadership. Journal of Quality and Participation, 25(4), 25-27.

Fombrun, C.J. (1996). Reputation. Boston, MA: Harvard Business School Press.

Frank, T. (1925) Roman Imperialism. New York: The Macmillan Company.

Fuhrer, T. (1989). Aeneas: A Study in Character Development. Greece \& Rome, 36(1), 6372.

Gaechter, S. \& Renner, E. (2003). Leading-by-example in the presence of free rider incentives. Workshop on Leadership and Social Interactions: Lyon.

Gale, M.R. (1997). The shield of Turnus. Greece \& Rome, 44(2), 176-196.

Galinsky, K. (1996) Augustan Culture. Princeton, NJ: Princeton University Press.

Gardner, J. (1980). Toward a pluralistic but coherent society. New York, NY: The Free Press.

Gardner, J. (1995). The cry for leadership. In J.T. Wren (Ed.), The leader's companion (pp. 3-7). New York, NY: The Free Press.

Garg, G., \& Krishnan, V.R. (2003). Transformational leadership and organizational structure: The role of value-based leadership. In S. Bhargava (Ed.), Transformational leadership: Value-based management for Indian organizations (pp. 82-100). New Delhi, India: Sage.

Gini, A. (1998). Moral leadership and business ethics. In J. Cillua (Ed.), Ethics, the heart of leadership. Westport, CT: Quorum Books.

Glader, P. (2009, December 14). GE's Immelt to cite lessons learned. The Wall Street Journal, p. B2.

Goleman, D. (2000). Leadership that gets results. Harvard Business Review, 78(2), 78-90.

Gouillart, F. \& Kelly, J. (1995). Transforming the organization. New York, NY: McGraw Hill.

Graber, D.R. \& Kilpatrick, A.O. (2008). Establishing values-based leadership and value systems in healthcare organizations. Journal of Health and Human Services Administration, 31(2), 179-197.

Gransden, K.W. (1984). Vergil's Iliad: An Essay on Epic Narrative. Cambridge: Cambridge University Press. 
Gransden, K.W. (1990) Virgil, The Aeneid. Cambridge: Cambridge University Press.

Green, J. (2009, November 11). Whitacre, critical of GM change pace, pressures CEO. Bloomberg. Retrieved from http://www.bloomberg.com

Green, P.E., Krieger, A.M., \& Yoram, J. (2001). Thirty years of conjoint analysis: Reflections and prospects. Interfaces, 31(3), 56-73.

Greenberg, J. (1990). Looking fair vs. being fair: Managing impressions of organizational justice. Research in Organizational Behavior, 12, 111-151.

Grimland, G. (2010, May 20). Intel insider. Haaretz. Retrieved from http://www.haaretz.com

Grojean, M.W., Resick, C.J., Dickson, M.W., \& Smith, D.B. (2004). Leaders, values and organizational climate: Examining leadership strategies for establishing an organizational climate regarding ethics. Journal of Business Ethics, 55(3), 223-241.

Guth, W., Levati, M.V., Sutter, M., \& Heijden, E. (2007). Leading by example with and without exclusion power in voluntary contribution experiments. Journal of Public Economics, 91(5), 1023-1042.

Hahn, E.A. (1931). Pietas versus Violentia in the Aeneid. The Classical Weekly, 25(2), 9-13.

Hamilton, E. (1932) The Roman Way. New York: Norton.

Hammond, M. (1933) The Augustan Principate in Theory and Practice During the JulioClaudian Period. New York: Russell \& Russell.

Hardie, P. R. (1985). Imago Mundi: Cosmological and Ideological Aspects of the Shield of Achilles. The Journal of Hellenic Studies, 105, 11-31.

Hewlett-Packard (2010). Hewlett-Packard History. Retrieved from http://www.hp.com

Holland, R. (2004). Augustus: Godfather of Europe. Gloucestershire, England: Sutton Publishing.

Hollander, R. (1968). Dante's use of Aeneid I in Inferno I and II. Comparative Literature, 20(2), 142-156.

Hood, J.N. (2003). The relationship of leadership style and CEO values to ethical practices in organizations. Journal of Business Ethics, 43(4), 263-273.

House, R.J., Hanges, P.J., Javidan, M., Dorfman, P.W. \& Gupta, V. (2004) Culture, leadership, and organizations: the GLOBE study of 62 societies: Global Leadership and Organizational Behavior Effectiveness Research Program. Sage: Thousand Oaks, CA.

Howe, G. (1930). The development of the character of Aeneas. The Classical Journal, 26(3), 182-193.

Jick, T. D. (1979). Mixing qualitative and quantitative methods: Triangulation in action. Administrative Science Quarterly, 24, 602-611.

Katzenbach, J.R. (1997). The myth of the top management team. Harvard Business Review, $75(6), 82-91$.

Kay, J. (1995). Why firms succeed. London, England: Oxford University Press.

Keating, S. (2010) Trust Deficit: A Challenge We Must Face Even After

Economy Grows Strong, Vital Speeches of the Day, 146-148.

Kolditz, T. (2007). In extremis leaders. Leadership Excellence, 24(10), 18.

Kopelman, R.E., Brief, A.P., \& Guzzo, R.A., (1990). The role of climate and culture in productivity. In B. Schneider (Ed.), Organizational culture and climate (pp. 282-318). San Francisco, CA: Jossey-Bass.

Korfmacher, W.C. (1956). Vergil, spokesman for the Augustan reforms. The Classical Journal, 51(7), 329-334.

Kotter, J. (1996). Leading change. Boston, MA: Free Press. 
Learned, E., Dooley, A., Katz R.L. (1959). Personal values and business decisions. Harvard Business Review, 37(2), 111-120.

Leebaert, D. (2006). To dare \& conquer. New York, NY: Little, Brown \& Co.

Lloyd, R.B. (1972). Superbus in the Aeneid. The American Journal of Philology, 93(1), $125-$ 132.

Louviere, J.J. (1988). Conjoint analysis Modelling of Stated Preferences: A Review of Theory, Methods, Recent Developments and External Validity. Journal of Transport Economics and Policy, 22(1), 93-119.

Lyne, R. (1983). Vergil and the politics of war. The Classical Quarterly, 33(1), 188-203.

MacKay, L.A. (1963). Hero and theme in the Aeneid. Transactions and Proceedings of the American Philological Association, 94, 157-166.

Majer, K. (2005). Values-based leadership: A revolutionary approach to business success and personal prosperity. Journal of Business Ethics and Organization Studies, 10(1), $42-$ 43.

Marmol, G., \& Murray, R. (1995). Leading from the front. McKinsey Journal, 3, 18-31.

Marshall, C., \& Rossman, G. B. (1989). Designing qualitative research. Newbury Park, CA: Sage.

Martin, J. Su, S.K., \& Beckman, C. (1997). Enacting share values - Myth or reality?: A context-specific values audit (Research Paper No. 1469). Graduate School of Business, Stanford University, Palo Alto, CA.

Maxwell, J.A. (1996). Qualitative research design: An interpretive approach. Thousand Oaks, CA: Sage.

Mayer, R.C., Davis, J.H., \& Schoorman F.D. (1995). An integrative model of organizational trust. The Academy of Management Review, 20(3), 709-734.

McDonald, M. (1972). Aeneas and Turnus: Labor vs. Amor. Pacific Coast Philology, 7, 4348.

McGushin, P. (1964). Virgil and the spirit of endurance. The American Journal of Philology, 85(3), 225-253.

McLeish, K. (1972). Dido, Aeneas, and the concept of 'Pietas' Dido. Greece \& Rome, 19(2), 127-135.

Messick, D.M., \& Bazerman, M.H. (1996). Ethical leadership and the psychology of decision making. Sloan Management Review, 37(2), 9-22.

Michels, A. (1997). The many faces of Aeneas. The Classical Journal, 92(4), 399-416.

Miller, F.J. (1928). Vergil's motivation of the Aeneid. The Classical Journal, 24(1), 28-44.

Mills, C. (2002). The hidden dimension of blue-collar sense-making about workplace communication. The Journal of Business Communication, 39(1), 288-313.

Moerk, E.L. (1998). From war-hero to villain: Reversal of the symbolic value of war and a warrior king. Journal of Peace Research, 35(4), 453-469.

Moorman, R.H., Niehoff, B.P., \& Organ, D.W. (1993). Treating employees fairly and organizational citizenship behaviour: Sorting the effects of job satisfaction, organizational commitment, and procedural justice. Employee Responsibilities and Rights Journal, 6, 209-225.

Morwood, J. (1991). Aeneas, Augustus, and the theme of the city. Greece \& Rome, 38(2), 212-223.

Moseley, N. (1925). Pius Aeneas. The Classical Journal, 20(7), 387-400.

Moyer, D. (2009). Fortitude or folly? Harvard Business Review, 87(9), 124 
Muscat, E., \& Whitty, M. (2009). Social entrepreneurship: Values-based leadership to transform business education and society. Business Renaissance Quarterly, 4(1), 3144.

Nestle (2010). Creating Shared Value (CSV). Retrieved from http://www.nestle.com/csv

O'Toole, J. (1995). The executive's compass: Business and the good society. Oxford, England: Oxford University Press.

Ovid (1916) Metamorphoses (Trans. F. Miller). Cambridge, Massachusetts: Harvard University Press.

Paine, L. S. (1994). Managing for organizational integrity. Harvard Business Review, 72(2), 106-117.

Papaioannou, S. (2003). Founder, civilizer and leader: Vergil's Evander and his role in the origins of Rome. Mnemosyne, (4th series), 56(6), 680-702.

Parry, K. W., \& Proctor-Thomson, S. B. (2002). Perceived integrity of transformational leaders in organizational settings. Journal of Business Ethics, 35(2), 75-96.

Plutarch (1914). Lives, I: Theseus and Romulus. Lycurgus and Numa. Solon and Publicola. (B. Perrin, Trans.). Cambridge, MA: Harvard University Press. (Original work published ca. 45-120 CE).

Pollack, A. (2010, April 10). Genzyme drug shortage leaves users feeling betrayed. New York Times. Retrieved from http://www.nytimes.com

Powell, C. (1996). My American journey. New York, NY: Random House Publishing.

Pruzan, P. (1998). From control to values-based management and accountability. Journal of Business Ethics, 17(13), 1379-1394.

Quint, D. (1989). Epic and empire. Comparative Literature, 41(1), 1-32.

Riccucci, N. M., \& Getha-Taylor, H. (2009). Managing the new normalcy with values-based leadership: Lessons from Admiral James Loy. Public Administration Review, 69(2), 200-206.

Richmond, J.A. (1976). Symbolism in Virgil: Skeleton key or will-o'-the-wisp? Greece \& Rome, 23(2), 142-158.

Rokeach, M. (1973). The nature of human values. New York, NY: The Free Press.

Ruggeri, A. (2009, October 22). Jim Sinegal: Costco CEO focuses on employees. US News \& World Report. Retrieved from http://www.usnews.com

Russell, R.F. (2000). The role of values in servant leadership. Leadership and Organization Development Journal 22(2), 76-83.

Sackett, P.R. \& Larson, J. Jr. (1990). Research strategies and tactics in industrial and organization psychology. In M. D. Dunnette \& L. M. Hough (Eds.). Handbook of Industrial and Organizational Psychology (pp. 419-489). Palo Alto, CA: Consulting Psychologists Press.

Scandura, T. A., \& Williams, E. A. (2000). Research methodology in management: Current practices, trends, and implications for future research. Academy of Management Journal, 43(6): 1248-1264.

Schmitt, B., \& Simonson, A. (1997). Marketing aesthetics: The strategic management of brands, identity, and image. New York, NY: The Free Press.

Sendjaya, S., \& Sarros J.C. (2002). Servant leadership: Its origin, development, and application in organizations. Journal of Leadership and Organization Studies, 9(2), 57-64.

Senge, P. (1990). The fifth discipline: The art \& practice of the learning organization. New York, NY: Double Day. 
Seutonius (2007) Twelve Ceasers (A. Thompson, Trans.). Stilwell, KS: Digireads.com Publishing.

Silverman, D. (1993). Interpreting qualitative data: Methods for analysing talk, text and interaction. London, England: Sage.

Smiley, P.O.R. (1948). In the steps of Aeneas. Greece \& Rome, 17(51), 97-103.

Tetenbaum, T.J. (1999) Beating the Odds of Merger \& Acquisition Failure: Seven Key Practices That Improve the Chance for Expected Integration and Synergies. Organizational Dynamics, 28(2), 22-36.

The National Archives. (2010). The Victoria Cross registers. Retrieved from http://www.nationalarchives.gov.uk

Thomas, D. (1993). Business sense: Exercising management's five freedoms. New York, NY: Free Press.

Thornton, A.H.F. (1953). The Last Scene of the 'Aeneid'. Greece \& Rome, 22(65), 82-84.

Tichy, N. (2009). A.G. Lafley, judgment, and the re-do loop [Web log comment, Jun 12]. Retrieved from http://blogs.hbr.org

Tichy, N. \& Bennis, W. (2010). Wise judgment. Leadership Excellence, 27(5), 5-6.

Toll, K. (1997). Making Roman-Ness and the "Aeneid". Classical Antiquity, 16(1), 34-56.

Tracy, H. L. (1964). 'Fata Deum' and the Action of the 'Aeneid'. Greece \& Rome, 11(2), 188195.

Van Lee, R., Fabish, L., \& McGaw, N. (2005). The Value of Corporate Values. Strategy + Business, 39, 1-14.

Virgil (1983). The Aeneid. (R. Fitzgerald, Trans.). New York, NY: Random House. (Original work published c. 20 BCE).

Wegner, H. (1977). Pius Aeneas and Totó, il Buono: The founding myth of the divine city. Pacific Coast Philology, 12, 64-71.

West, D. (1994). In the Wake of Aeneas. Greece \& Rome, 41(1), 57-61.

Whyte, D. (1994) The Heart Aroused. New York, NY: Random House.

Williams, S. (1999). The effects of distributive and procedural justice on performance. The Journal of Psychology, 133(2), 183-193.

Wilson, J.R. (1969). Action and emotion in Aeneas. Greece \& Rome, 16(1), 67-75.

Wiltshire, S.F. (1991). Public and private in Vergil's Aeneid. The Classical Journal, 87(2), 182-189.

Wren, J.T., \& Swatez, M.J. (1995). The historical and contemporary contexts of leadership: A conceptual model. In J.T. Wren (Ed.), The leader's companion (pp. 245-252). New York, NY: The Free Press.

Yin, R. K. (1984). Case study research: Design and methods. Beverly Hills, CA: Sage.

Yoon, K.P., \& Hwang, C.L. (1995). Multiple attribute decision making. Thousand Oaks, CA: Sage.

Zell, D.M., Glassman, A.M., \& Duron, S.A. (2007). The short and glorious history of accelerated decision making at Hewlett-Packard. Organizational Dynamics, 36(1), 93-104. 